\title{
COX2: A Prognostic Inflammogenic Marker Drives Cervical Carcinogenesis in Vivo through the NFkB/IAP/p53Axis
}

\section{ELIZABETH MAHAPATRA}

Chittaranjan National Cancer Institute

\section{SOUVICK BISWAS}

Chittaranjan National Cancer Institute

\section{SALINI DAS}

Chittaranjan National Cancer Institute

\section{MADHUMITA ROY}

Chittaranjan National Cancer Institute

SUTAPA MUKHERJEE ( $\square$ sutapa_c_in@yahoo.com )

Chittaranjan National Cancer Institute https://orcid.org/0000-0002-4411-7257

\section{Research Article}

Keywords: COX2, NFKB, IAPs, p53, inflammation, cervical cancer

Posted Date: September 3rd, 2021

DOI: https://doi.org/10.21203/rs.3.rs-849980/v1

License: @ (1) This work is licensed under a Creative Commons Attribution 4.0 International License. Read Full License 


\section{Abstract}

Cycloxygenase 2, a prostaglandin synthesizing enzyme, is a key player in inflammation-induced vasculogenesis that enables tumor growth. This study explores the central role of COX2 and its relative prosurvival proteins in evoking inflammatory events during the development of an in vivo cervical cancer model upon chronic treatment with 3-methylcholanthrene (3MC; a chemical carcinogen) in virgin-female Swiss albino mice. Chronic painting of the mouse cervix with $3 \mathrm{MC}$ solution triggered the persistent expression and activity of COX2, eventuating the overexpression of major prosurvival molecules (NFKB, XIAP, survivin, GM-CSF1) and proliferative antigens (Ki67, PCNA). COX2-arbitrated prosurvival signaling subsequently deranged the expression profiles of tumor suppressor proteins (p53/acetyl-p53, p21, Rb) within the cervix. COX2 mediated molecular alterations successively surged leukocyte influx within the cervix, catering to localized inflammation that gradually distorted its tissue architecture. Cervical carcinogenesis was further braced by higher levels of systemic ROS and RNS, escalated iNOS activity and compromised antioxidant enzyme capacities, which were accompanied by splenomegaly. Additionally, circulation of blood leucocytes with damaged DNA throughout the mouse body envisaged the impact of cervix-limited inflammation on mouse physiology. Conclusively, the present study deciphered the role of $C O X 2$ in affecting $N F K B / I A P / p 53$ functions in sequestering the contributors of localized and systemic inflammogenesis to propel 3MC-mediated cervical carcinogenesis in vivo.

\section{Introduction}

Cycloxygenase 2 (COX2) is preeminent in the inflammogenesis of cancers. Formally termed the prostaglandin H2 synthase-2 enzyme, COX2 catalyses the rate-limiting step of mitochondrial fatty acid oxidation concerning the conversion of arachidonic acid to biologically active prostanoids, which are propagators of inflammation [1, 2]. These prostanoids maintain COX2 expression to activate ROS/AKT/activator protein 1 [3] and switch on kinase cascades $[4,5]$ to enable malignant transformations. In addition, COX2 promotes angiogenesis, the hallmark episode of new blood vasculature growth in solid tumors, which assists them in independent sustainment. Vascular endothelial growth factor (VEGF), the key regulator of the 'angiogenic switch', is also instructed by COX2 to promote endothelial growth $[6,7]$. Therefore, research on the contributions of COX2 to various neoplastic processes is increasing.

With a chromosomal location of $1 \mathrm{q} 31$, the COX2 gene is highly inducible in nature [8] because it is overtly expressed for organizing inflammatory events only upon viral oncogenic inductions, chemical carcinogenic triggers or pathological conditions that develop due to chronic viral or bacterial infections $[9,10]$. In the incidences of human papillomavirus (HPV)-mediated cancers such as cervical and oral carcinomas, an extended viral latency period was found to be closely associated with COX2-generated noncompensatory inflammation states [11]. Similarly, persistent xenobiotic exposure induced COX2 activities, which reportedly enhanced skin inflammation, bringing forth carcinogenesis [12]. Recent experimental reports are evidence for the prerequisite need for $\mathrm{COX} 2$ in cancer stem cell differentiation and proliferation [13, 14]. Polycyclic aromatic hydrocarbons (PAHs) of lower molecular weight emitted along with cigarette smoke were found to affect p38 MAP kinase to cause COX2 mRNA overproduction. As a consequence, eicosanoid signaling began within the lung epithelium to initiate carcinogenic changes [15]. Often, in lymphomas, COX2 observably upgrades the proliferative, angiogenic and invasive potentials of leukocytes $[16,17]$. Multiple cancers are characterized by genetic aberrations along with polymorphisms in their COX2 gene [18-22]. 
Several interesting documentations suggest that COX2 is central to inflammation, angiogenesis and tumorigenic progression $[23,24]$. Aberred COX2 inflammation becomes the 'formative ground'of a strong prosurvival signaling network characterized by deteriorated tumor suppressor activities. Generally, it is a common observation that gain-of-function mutations in the effector genes of the Ras-MAPK and PI3K/AKT signaling pathways principally dictate malignant transformation processes. Reportedly, COX2 could potentiate many cancers by phenotypically mimicking the effects of these two pathways, even when the concerned driver mutations are absent [25]. In hypoxic tumor cores, an increase in the expression of hypoxia inducible factor-1 (HIF-1) collaterally accelerates COX2 kinetics to permit the expression of nuclear factor $K B(N F K B)$ [26] and its effector inhibitor of apoptosis proteins (IAPS) [27]. COX2-derived prostanoids further activate the MAPK pathway to allow VEGF translation, aiding in vasculogenesis $[28,29]$. Additionally, COX2 adorns functionality by repressing tumor suppressors such as $\mathrm{p} 53$, p21 or $\mathrm{Rb}$ and over activating $\mathrm{Bcl}_{2}$, an antiapoptotic protein [30, 31]. The relentless cytokine storm following COX2 activation relays dysregulated inflammatory signals that alter the functional differentiation of immune cells to promote tumorigenesis [32]. COX2 and related cytokines are responsible for switching the developmental fate of 'tumor-inhibiting' $\mathrm{M} 1$ macrophages to 'tumor-promoting' $\mathrm{M} 2$ macrophages or tumor-associated macrophages (TAMs) [33,34]. Therefore, COX2 and its effectors empower a growing tumor mass with the armour of immune evasion [35]. Inevitably, COX2 is the prima facie requirement for promoting autonomous tumor growth.

With regard to the prevalent reports, the present study was designed to investigate the mediating role of COX2 in domineering the inception and progression of cervical carcinogenesis within Swiss albino mice upon chronic treatment with 3-methylcholanthrene (3MC), a potent chemical carcinogen of the PAH family. This study systematically dismantled the role of COX2 in sequestering inflammogens to drive the activation of the prosurvival signaling nexus to promote cervical carcinogenesis in vivo.

\section{Material And Methods}

\section{Animal Maintenance}

Virgin female Swiss albino mice (Mus musculus; 5-6 weeks old; weight: 23-25 gms) obtained from the Central Animal Facility of $\mathrm{CNCl}$ were housed in polyvinyl cages within well-ventilated rooms under ideal conditions (temperature: $22^{\circ} \mathrm{C}$; relative humidity: 50-60\%; 12-hour day/night cycle). Prior to treatment initiation, the animals were subjected to a two-week acclimation period during which all the female and male mice were kept in complete isolation from each other. This induced pheromone influenced estrous cycle synchrony, thereby nullifying hormonal interferences [36]. Standard guidelines laid down by the Institutional Animal Ethics Committee (IAEC) certified by the Committee for the Purpose of Control and Supervision of Experiments on Animals (CPCSEA), New Delhi, India, were strictly followed for undertaking all animal experimentation.

\section{Experimental design}

Random allocation of 100 mice into three broad groups was accomplished on the basis of body weight.Each group was further classified into subgroups separated into two batches of 10 animals [No of mice (n) =5/cage (x2) for each subgroup]. Group I was kept as an 'untreated' control group where mice did not receive any treatment. Group III (groups 6-10) comprised mice that had their cervix chronically painted with 3MC (MP 
Biomedicals, USA) solution prepared in petroleum ether (PET, Merck, Emplura, Germany) for intervals of 6, 12, 16, 24 and 30 weeks [37]. It was specifically designated the 'treatment' group for studying cervical carcinogenesis over these time spans. To rule out any carcinogenic effect of the solvent (if any), Group II (groups 1-5) was assigned as a 'vehicle control' batch, with mice being solely treated with PET. Food and water was given ad libitum. Mice were periodically monitored for any visible health abnormalities and deaths. This purposeful procedure of mouse grouping is well represented in Table 1.

\section{Record of body weight and carcinogenic incidences}

Weekly body weight alterations in mice were recorded to assess the impact of chronic 3MC and PET treatments on their physiology with time. An orderly record of tumor incidences along with gradually acquired cervical dysplastic stages in the 3MC-treated mouse batches was also maintained.

After every mentioned treatment period, mice from all three groups were sacrificed, and their entire female reproductive tissue was excised out. To track the presence of any cervical tumor, these reproductive tissues were longitudinally opened up for examination through its upper vaginal (ectocervix) region. Cervix tissues (with or without tumor) were decapitated for comparative studies. In addition to the cervix, blood and spleen were also collected for experimental purposes.

\section{Cytopathological study}

Smears of cervical exfoliated cells suspended in phosphate-buffered saline (PBS, pH 7.4) were fixed with $100 \%$ ethyl alcohol and stained as per the protocol of Mahapatra et al. (2020) [37]. Sequential polychromatic staining with Harris hematoxylin ( $\mathrm{HH}$ ), orange G6 (OG6) and eosin azure (EA50) [Merck Millipore, Mumbai, India] followed by excess stain removal in tap water and $70 \%$ and $90 \%$ alcohol was observed. Finally, stained slides were mounted and observed under a light microscope (Zeiss). Fifty fields were randomly scanned for the presence of significant cytopathological changes in each slide.

\section{Enumeration of differential count of cervical leukocytes}

A numerical count of the microscopically identified subpopulations of cervical leukocytes was quantitated as 'Differential Leukocyte Count' (DLC). Over 50 fields of Pap-stained slides were randomly scanned to calculate DLC. For each field, DLC was enumerated as a percentage (\%) of the specific number of leukocyte subpopulations (eosinophils, neutrophils and monocytes) observed among the total number of leukocytes [DLC= (Number of specific types of leukocytes)/(Total number of leukocytes) $\times 100]$.

\section{Histology}

Dissected cervical and spleen tissues were washed in cold normal saline (0.9\%), fixed in 10\% (w/v) neutral buffered formalin (NBF) for $24 \mathrm{~h}$, processed through alcohol grades and xylene, and embedded in paraffin. These paraffinized tissue blocks were cut into thin $(\sim 5 \mu \mathrm{m})$ sections using a microtome and stretched over grease-free glass slides. These sections were further deparaffinized in xylene followed by successive staining in 
Delafield haematoxylin [DH; haematoxylin powder, $100 \%$ alcohol, $\left(\mathrm{NH}_{4}\right) \mathrm{Al}\left(\mathrm{SO}_{4}\right)_{2}$, glycerol, $\left.\mathrm{H}_{2} \mathrm{O}\right]$ and $2 \%$ eosin. After mounting, 10-20 fields of these stained slides were examined under a light microscope (Zeiss) to document the histological changes.

\section{Immunohistochemistry}

Cervical tissue sections ( $5 \mu \mathrm{m}$ thick) were stained with primary antibodies against COX2, NFkB (p50/p65), XIAP, survivin, Ki67 and PCNA proteins to locate them within tissues by following the protocol of Basu et al. (2020) [38]. Paraffin from stretched tissue sections was removed by heating the slides at $65^{\circ} \mathrm{C}$ for 20 min followed by xylene treatment and rehydration through 100\%, 90\%, 70\% and 50\% alcohol downgrades. After washing these sections serially in PBS for $10 \mathrm{~min}$, 'antigen retrieval' was carried out using preheated citrate buffer [pH-6; comprising $\mathrm{C}_{6} \mathrm{H}_{8} \mathrm{O}_{7} \cdot \mathrm{H}_{2} \mathrm{O}$ and $\left(\mathrm{CH}_{2} \mathrm{COONa}\right)_{2} \cdot 2 \mathrm{H}_{2} \mathrm{O}$ ] at $85^{\circ} \mathrm{C}$ for $1 \mathrm{~h}$, after which they were incubated with the respective primary antibodies diluted in $1 \%$ bovine serum albumin (BSA; Sigma Aldrich, USA) solution within a humid chamber overnight at $4^{\circ} \mathrm{C}$. Excess primary antibodies were washed in $1 \mathrm{X}$ PBS. Slides were further incubated with HRP-conjugated secondary antibodies $(1: 500)$ in $1 \%$ BSA solution for $2 \mathrm{~h}$ at $37^{\circ} \mathrm{C}$ followed by immunostaining with the chromogenic substrate 3-3' diaminobenzidine (DAB; Santa Cruz Biotechnology, USA) and counterstaining with $\mathrm{DH}$. These slides were dehydrated through successive alcohol grades and xylene. Finally, they were mounted in DPX for observation under a light microscope (Zeiss). Approximately ten fields were scanned to score the positive staining intensities. Staining intensities $(1=$ weak, 2 $=$ moderate, 3 = strong) were enumerated as per the percentage of positively stained cells $(<1=0,1-20=1$, $20-50=2,50-80=3$ and $>80=4)$. The final evaluation of tissue-specific protein expression was made as low (score 0-2), intermediate (2-5), and high (score 5-7) levels.

The primary antibodies employed were COX2 (GeneTex, 1:1000), NFkB (p50/p65) (GeneTex, 1:1000), Ki67 (GeneTex, 1:1000), PCNA (GeneTex, 1:1000), XIAP (GeneTex, 1:1000) and survivin (GeneTex, 1:1000).

\section{Preparation of tissue lysates}

Cervix tissues along with the adjoining tumor regions were dissected out, washed, and pooled separately from Group I, II and III mice. Tissue and tumor parts were dried, weighed and homogenized in radioimmunoprecipitation assay lysis buffer(RIPA; $\mathrm{pH}-8$ comprising $5 \mathrm{M} \mathrm{NaCl}, 0.5 \mathrm{M}$ EDTA, 1 M Tris, NP-40, 10\% sodium deoxycholate, $10 \%$ SDS). The extracts were kept on ice for $30 \mathrm{~min}$ followed by sonication and centrifugation at $10,000 \mathrm{~g}$ for $20 \mathrm{~min}$ at $4^{\circ} \mathrm{C}$. The resulting supernatants were stored in chilled vials at $-20^{\circ} \mathrm{C}$.

\section{Estimation of total protein}

The total protein content of the tissue extracts was spectrophotometrically (VARIAN) estimated using $1 \mathrm{X}$ Bradford's reagent (HIMEDIA, PA, USA) against a standard curve of BSA. Absorbance was recorded at $595 \mathrm{~nm}$, and the experiment was repeated 5 times.

\section{Western Blot Analysis}


The expression statuses of inflammatory mediators (COX2, GM-CSF1), tumor suppressor proteins [p53, acetylated-p53 (lys373), p21, Rb], prosurvival molecules (NFKB, XIAP, survivin) and proliferative antigen (Ki67) were comparatively studied by western blotting. Equitable amounts of cervical protein were loaded into each well of SDS-polyacrylamide (SRL, Mumbai, India) gels, electrophoretically separated using electrophoresis buffer (25 mM Tris, $192 \mathrm{mM}$ glycine, 10\% SDS) and electrotransferred to nitrocellulose membranes with the aid of transfer buffer ( $250 \mathrm{mM}$ Tris, $192 \mathrm{mM}$ glycine, $10 \%$ methanol). These membranes were blocked with $5 \%$ (w/v) BSA solution and washed with Tris-buffered saline (TBS; pH 7.5; $25 \mathrm{mM}$ Tris. $\mathrm{HCl}, 150 \mathrm{mM} \mathrm{NaCl}$ ) and incubated overnight with primary antibodies at $4^{\circ} \mathrm{C}$ under constant shaking. Blots were thereafter washed with TBST Buffer solution (TBS; Tween 20) 4 times and subsequently incubated with alkaline phosphatase conjugated secondary antibodies (GeneTex, 1:500dilutions in TBS) at $4^{0} \mathrm{C}$ for $2 \mathrm{~h}$, followed by TBST washing (4times) and incubation with the chromogenic substrate 5-bromo, 4-chloro, 3-indoylphosphate/ Nitro-Blue tetrazolium (BCIP/NBT; SantaCruz Biotechnology, USA) for visualizing protein expressions in the form of bands. $\beta$-actin was used as a loading control protein. These experiments were performed in triplicate.

The primary antibodies used were COX2 (GeneTex, 1:1000), GM-CSF1 (Santa Cruz, 1:1000), NFkB (p50/p65) (GeneTex, 1:1000), Ki67 (GeneTex, 1:1000), PCNA (GeneTex, 1:1000), XIAP (GeneTex, 1:1000), survivin (GeneTex, 1:1000), acetyl p53 (lys 373) (Merck-Millipore, 1:1000), p53, p21, Rb (Santa Cruz, 1:1000) and $\beta$-actin (GeneTex, 1:1000).

\section{Quantitative estimation of COX2 activity}

COX2 enzyme (E.C 1.14.99.1) was spectrophotometrically quantitated at $590 \mathrm{~nm}$ using a COX activity assay kit (Cayman Chemical, Cat No: 760151 Ann Arbor, MI, USA) as per the provided protocols. The results are presented in $\mathrm{nmol} / \mathrm{min} / \mathrm{ml}$ (U/mg of protein).

\section{Isolation of blood leukocytes}

One volume of mouse blood collected aseptically from the heart was mixed with three volumes of Solution A (pH-7.2; $0.87 \% \mathrm{NH}_{4} \mathrm{Cl}$ in $10 \mathrm{mM}$ Tris $\mathrm{HCl}$ ), incubated on ice for 20 min and centrifuged at $400 \mathrm{~g}$ for $20 \mathrm{~min}$ at $0^{\circ} \mathrm{C}$. The supernatant was discarded, and the pellets were again resuspended in Solution A followed by centrifugation at $400 \mathrm{~g}$ for another $20 \mathrm{~min}$ at $0^{\circ} \mathrm{C}$. The resulting pellets were suspended in Solution $\mathrm{B}(\mathrm{pH}-7.2$; $0.25 \mathrm{M}$ mesoinositol, $10 \mathrm{mM} \mathrm{Na} 2 \mathrm{SO} 4,1 \mathrm{mM} \mathrm{MgCl}_{2}$ ), cold centrifuged at $1500 \mathrm{rpm}$ for $5 \mathrm{~min}$ at $4^{\circ} \mathrm{C}$, and resuspended in HEPES-buffered saline (HBS; pH 7.4; $140 \mathrm{mM} \mathrm{NaCl}, 5 \mathrm{mM} \mathrm{KCl}, 10 \mathrm{mM} \mathrm{HEPES}, 1 \mathrm{mM} \mathrm{CaCl} 2,1$ $\mathrm{mM} \mathrm{MgCl} 2,10 \mathrm{mM}$ glucose). Cell numbers were adjusted as per experimental requirements.

\section{ROS generation}

Reactive oxygen species (ROS) generated due to chronic treatment with $3 \mathrm{MC}$ was quantitated according to the principle of Sinha and Roy (2010) [39]. Isolated leukocytes ( $10^{6} \mathrm{cells} / \mathrm{ml} /$ point) suspended in HBS were incubated with a fluorescent probe, 2',7'-dichlorofluorescein dihydroacetate or DCFH-DA (10 $\mu \mathrm{M}$, Sigma-Aldrich, USA), for $45 \mathrm{~min}$ at room temperature in complete darkness. DCFH-DA passively diffuses within cells to 
transform into a diol moiety, which is further oxidized into a fluorescent compound, 2', 7'-dichlorofluorescein (DCF), by intracellular ROS. DCF was quantitated spectrofluorimetrically (VARIAN; Excitation: $485 \mathrm{~nm}$ and Emission: $530 \mathrm{~nm}$ ). For each point, readings were recorded approximately five times in triplicate attempts of the experiment.

\section{RNS generation}

Equal volumes of peritoneal macrophage suspension $\left(10^{6} \mathrm{cells} / \mathrm{ml}\right)$ in PBS and Griess reagent $(1 \%$ sulphanilamide, $0.1 \%$ naphthyl ethylenediamine hydrochloride and $5 \%$ orthophosphoric acid) were incubated at $37^{\circ} \mathrm{C}$ for $30 \mathrm{~min}$ in a humidified chamber to quantify reactive nitrogen species (RNS) levels [40]. Absorbance was recorded at $550 \mathrm{~nm}$ with a spectrophotometer (VARIAN) against a standard blank. NO levels were enumerated against a standard curve of sodium nitrite. Readings for each point were taken approximately five times in triplicate.

\section{Quantitative estimation of nitric oxide synthetase activity}

Indirect assessment of nitric oxide synthetase (iNOS) enzyme (E.C1.14.13.39) activity was performed using a spectrophotometer by calculating the percentage of L-citrulline catalytically produced from L-arginine by means of a NOS activity assay kit (Cayman Chemical, Cat No: 781001, Ann Arbor, MI, USA) in accordance with the kit instructions.

\section{Antioxidant Enzyme Activity}

The free radical quenching capacity of the antioxidant scavengers present in the blood serum isolated using serum separating vials was assessed with the help of an antioxidant assay kit (Cayman Chemical, Cat No: 709001, Ann Arbor, MI, USA). Enzyme activity was expressed as IU/L with the help of a spectrophotometer, where readings were recorded within the absorbance range of 405-750 nm.

\section{Single-cell gel electrophoresis (SCGE or comet assay)}

The clastogenic effect of $3 \mathrm{MC}$ on DNA was assessed following the standard laboratory protocol [41]. Concisely, a suspension of $0.6 \%(\mathrm{w} / \mathrm{v})$ low melting agarose (LMA; Sigma-Aldrich, USA) and isolated leukocytes $(1 \times 104$ cells) was smeared over a frosted microscopic glass slide that was priorly coated with fixative $0.75 \%(\mathrm{w} / \mathrm{v})$ normal melting agarose (NMA; Lonza, USA). Following solidification at $4^{\circ} \mathrm{C}$, cell and nuclear membranes were lysed in lysis buffer (pH-10; $2.5 \mathrm{M} \mathrm{NaCl}, 0.1 \mathrm{M} \mathrm{Na}_{2}$ EDTA, $10 \mathrm{mM}$ Tris, $0.3 \mathrm{M} \mathrm{NaOH}, 1 \%$ Triton X-100, and 10\%DMSO). Exposed DNA from the lysed leukocytes was unwound in highly alkaline electrophoresis buffer (pH $>13.0 ; 300 \mathrm{mM} \mathrm{NaOH}, \mathrm{I} \mathrm{mM} \mathrm{Na}{ }_{2}$ EDTA) prior to electrophoresis for $20 \mathrm{~min}(300 \mathrm{~mA}, 20 \mathrm{~V})$. Slides were washed in neutralizing buffer (Tris $0.4 \mathrm{M}, \mathrm{pH}$ 7.5) three times, stained with ethidium bromide (final concentration $40 \mu \mathrm{g} / \mathrm{ml}$ ) and examined under a fluorescence microscope (Leica). Image analysis, head DNA quantification, comet tail DNA length estimation and comet tail moment calculation were performed using Komet Software. 


\section{Statistical Analysis}

The mean values of the control, vehicle control and treatment mouse groups were compared by factorial analysis of variance (ANOVA). The relationship between the studied parameters was analysed by calculating Pearson's correlation coefficient using the CORREL function of Microsoft Excel. Data are expressed as the mean

\pm standard deviation (S.D.). $p$ value calculations were performed using GraphPad Prism Software. ${ }^{*} \mathrm{p}<0.005$ and ${ }^{* *} \mathrm{p}<0.01$ were considered statistically significant in comparison to control batches.

\section{Results}

The optimum $3 \mathrm{MC}$ dose of $0.6 \mathrm{mg} / \mathrm{ml}$ was selected as the safest and most efficacious treatment dose (<LD50) only after checking its impact on in vivo toxicity parameters, namely, SGPT, SGOT, ALP and creatinine levels (data not shown). The carcinogen preparation process is elaborated in Fig. 1A. Treatment durations of 6, 12, 16, 24 and 30 weeks were also accordingly identified. A clear schematic outline of the experimental design with an appropriate timeline of animal sacrifice is illustrated in Fig. 1B.

\section{Emergence of tumors in the cervical region upon chronic $3 \mathrm{MC}$ treatment}

Prior to sacrifice, the experimental mice were preliminarily monitored for any apparent changes in the appearance of their orifice and internal female reproductive organ owing to chronic treatment with PET or 3MC. Relevant observations noted among mice in Groups I, II and III are comparatively depicted in Fig. 2A and 2B. Obvious progressive changes in the vaginal orifice of 3MC-treated mice (Fig. 2Axi-xv) were an outcome of internal changes in their reproductive system (Fig. 2B). As indicated in Fig. 2Biv and v, remarkable alterations of the mouse reproductive organs after 12 and 16 weeks of $3 \mathrm{MC}$ treatment mostly included mild thickening along with growth of new blood vasculature. Group III mice from the 16th week batches had a mildly swelled orifice (Fig. 2Axiii; indicated by arrow). Further extending 3MC treatment beyond 24 weeks resulted in tumor growth at the cervical region (Fig. 2Bvi), leading to explicit swelling of the lower abdominal area (Fig. 2Axiv \& xv; indicated by arrows). No such abnormalities were noted in the vehicle control and control mice either amidst the treatment intervals or after 24 weeks.

Cytopathological changes in terms of increased 'keratinization' of the cervical squamous epithelial cells bearing 'nuclear holes' (Fig. 2Cxii; indicated by arrows) became perceptible amongst 3MC-treated mice in the 12th week. Inflammation mediating leukocytes such as eosinophils, neutrophils and monocytes was also persistently apparent in the cervical infiltrations (Fig. 2Cxiii) during the entire treatment span. In the 24th and 30th weeks, the mouse cervical exfoliates exhibited 'hyperchromatic nuclei' (Fig. 2Cxiv; indicated by arrows), assumed up a 'bizarre-structure' and harboured a 'perinuclear halo' (Fig. 2Cxv, indicated by arrows) as signs of 'vacuolation'. Cellular distortions of these types were clearly absent in PET-treated groups. Acquired observations were comparable with control animals.

Noticeable cytopathological alterations in the cervix necessitated exploration of its histology, which vividly exhibited transfigurations, as revealed by the presence of mild to severe cervical dysplasia (Fig. 2Diii \& iv) in mice exposed to $3 \mathrm{MC}$ for 6 and 12 weeks. Interestingly, the development of 'invasive carcinoma' eventuated 
with extension of treatment up to 16 weeks (Fig. 2Dv). Furthering 3MC treatment to 24 weeks and beyond resulted in disorientation of cervical epithelial layers (Fig. 2Dvi). As clearly comprehensible from the micrographs, no such remodeled cervical tissue features were discerned amongst the vehicle control and control mice even after 24 weeks (Fig. 2Di \& ii). These aforementioned changes were consistent with the attainment of a cervical tumor. The rates of incidences of the attained dysplastic changes and tumors among Group III mice are clearly shown in Table 2B. Moreover, chronic 3MC treatment affected the body weight of mice. The findings tabulated in Table 2A depict a gradual loss in body weight of these mice after 6 weeks of $3 \mathrm{MC}$ treatment, which continued until 12 weeks ( $25 \pm 0.1716 \mathrm{gms})$. A significant weight reduction of $24 \pm 0.0100$ gms was observed in the 16th week, which further increased by $29.1067 \pm 0.1940$ gms in the 24th week and beyond. Therefore, the decreasing trend in body weight was violated by a consistent rise in the 30th week of 3MC treatment.

\section{Chronic 3MC treatment rendered persistent cervical inflammation}

3MC triggered chronic cervical inflammation in mice, as unveiled from the foregoing cytopathological excerpts demanded a thorough investigation through its nature. Enumerated DLC (\%) values for Group I, II and III mice, as displayed graphically in Fig. 3A-C, revealed a dominance of neutrophils over other leukocytes in the mouse cervix upon continual 3MC exposure. Eosinophils in the 6th week and 12th week of 3MC treatment had DLC values of $25.11 \pm 0.58 \%$ and $35.01 \pm 0.58 \%$, respectively, which underwent a slight negative deviation of approximately $32.30 \pm 0.58 \%$ in the succeeding 16th week. Conversely, neutrophils of diverse morphologies (Fig. $3 \mathrm{E})$, with relatively higher DLC values (16th week: $52.13 \pm 1.00 \%$; 24th week: $66.33 \pm 1.00 \%$; 30 th week: $78.01 \pm$ $0.58 \%)$, gradually replaced the eosinophilic multitude in the cervix. Subsequently, with increasing treatment duration, monocytes also joined the cervical neutrophil milieu for maintenance of 3MC-induced inflammation, which could have possibly redesigned the cervical tissue architecture. Macrophages, although sparsely noted, were also obtained in the cervical infiltrates of these mice. An anecdote of cervical leukocyte infiltration trends among Group III mice is very well depicted in Fig. 3C. In Group II mice, transient neutrophil infiltration was apparent only at the 16th week of PET treatment (Fig. 3B). Such short-lived inflammation was not efficacious enough to eventuate in cervical neoplasia. The observations were comparable with those of control mice from Group I. Micrographic snippets of the varied cervical leukocytic subpopulations comprising eosinophils, neutrophils and monocytes among 3MC-treated mice are vividly portrayed in Fig. 3D.

\section{Incessant cervical inflammation was accompanied by the development of squamous cell carcinoma}

Following overall analysis of cervical histology among the 3MC-treated groups, the cervical tumor that emerged particularly at or after 24 weeks of 3MC administration was regionalized into 'cortical', 'cortico-medullary' and 'medullary' regions for histopathological characterization. Histological examination of the tumor cortex (Fig. 4, indicated by arrows) hinted towards a loss of tissue organization owing to the presence of large keratin pearls. Upon delving into the corticomedullary region, distortion of squamous epithelial cells (indicated by arrows) was remarkably noted. Squamous epithelial cells abnormally transformed into 'giant tumor cells' (indicated by arrows) harboring aggregation of multiple nuclei in their center (Fig. 4, lower left panel). A glimpse of the medullary tumor core further revealed the presence of epithelial regions (indicated by arrows) that might have invaded into the stroma from the overlying tissue tier (Fig. 4, lower right panel). These histopathological 
findings annotated the development of aggressive and poorly differentiated 'anaplastic squamous cell carcinoma' in the mouse cervix due to chronic inflammation produced by 30 weeks of 3MC treatment.

\section{Role of the inflammogenic mediator COX2 in 3MC-induced carcinogenic changes}

Spleen conditions were thoroughly studied to identify the systemic source of leukocytes augmenting cervical inflammation. A comparative overview of the splenic anatomy and histology is depicted in Fig. 5Ai-iv. Splenomegaly was deciphered in 3MC-treated mice at and after the 16th week. Corresponding splenic histopathology (Fig. 5Aiii \& iv) exhibited profuse eosinophil infiltrations (indicated by arrows), along with the prevalence of an increased number of 'germinal centres' with intense eosin stained peripheries (indicated by arrows). These results affirmed accelerating rates of leucopoiesis, which were primarily incited in the mouse body to combat 3MC-induced cervical toxicity. However, dysregulated inflammation antagonistically paved the way for cervical carcinogenesis by further activating inflammogens. Spleen tissues isolated from vehicle control and untreated mice at the 16th week were devoid of such histological remodelling.

The reproductive tissues isolated from these mouse batches appeared to be strangled with blood vessels (Fig. $5 \mathrm{~B}$; indicated by arrows). This kind of vasculogenic change is the product of carcinogenesis-enabling vector inflammatory reactions, which thereafter prompted the subsequent exploration of the responsible molecular interactome involving COX2. According to western blot results (Fig. 5D), cervical COX2 expression in mice increased with 3MC treatment extension. An elevated COX2 level in the tumor core was characteristically noted from the study of differential COX2 expression patterns in various tumor regions (Cortex-Tumor ${ }_{\text {COR }}$; Corticomedullary- Tumor COR/MED; Medulla- Tumor $_{\text {MED }}$ ). Further assessment of the functional status of COX2 was performed by IHC, wherein COX2 was found to be spatially distributed in the brown-stained nucleus and cytoplasm (Fig. 5C) of cervical tissue sections obtained from 3MC-treated mice in the 16th and 24th weeks. High-intensity staining of approximately $60.44 \%$ (6/10 mice) and 72.69\% (7/10 mice) was scored among these respective groups (Fig. 5D).

These findings endorsed an increasing trend in cervical COX2 activity (Fig. 5E). Significantly increased COX2 activity (12th week: $3.8 \pm 0.0091 \mathrm{U} / \mathrm{mg} ; 16$ th week: $5.72 \pm 0.016 \mathrm{U} / \mathrm{mg}$ ) in the mouse cervix continued to rise consistently even in the 24th and 30th weeks of 3MC treatment. This cumulative increase in the expression and activity of COX2 protein was found to be very strongly correlated $(r=0.9750 ; p<0.005)$ among the 3MC-treated groups (Table 3A). COX2 activities among vehicle control mice were on par with the control data.

\section{Inflammation-mediated COX2 activation propagated into subsequent overexpression of NFKB, GM-CSF1 and Ki67}

A gain in the expression of NFKB, GM-CSF1 and Ki67 (Fig. 6A), as obtained from western blot results, delineated the pathway taken by activated COX2 for promoting carcinogenesis. To establish the possibility of COX2 being the culprit in upregulating NFKB (p50/p65), GM-CSF1 and Ki67, correlation coefficients were calculated and represented in a tabulated format (Table 3A). Evidentially, a strong positive correlation between each of these parameters was mathematically obtained, which further strengthened the notion.

An earlier experimental observation attained by the team with the same model revealed the presence of upregulated cervical IL6 and IL8 activities alongside high expression [37]. These are also upstream activators of 
COX2 that fuel a plethora of prosurvival signaling molecules. Consequently, further study elevated granulocyte macrophage colony stimulating factor 1 (GM-CSF1) expression, as evident from the incremental band intensity patterns (Fig. 6A, lower panel), corroborating the frequent flux of neutrophils in the cervix (Fig. 3C). This justified the convinction that the cytokines IL6, IL8 and GM-CSF1, along with upregulated COX2, resulted in an increase in NFKB expression (Fig. 6A, upper panel). Consistent with COX2 expression, NFkB (p50/p60) subunits were very frequently localized within the nucleus at the tissue level (Fig. 6B, upper panel). In the micrographic excerpts of IHC tissue sections sampled from mice subjected to 16 and 24 weeks of $3 \mathrm{MC}$ treatment, positive nuclear staining for both the p65 and p50 subunits of the protein was attained. High-intensity positive nuclear staining for $p 50$ and p65, enumerating $78.77 \%$ (8/10 mice) and 82.03\% (8/10 mice), was scored among the 16th week mouse groups (Fig. 6B, lower panel). Respective protein expression scores stoking to approximately $80.23 \%$ ( $8 / 10$ mice) and $86.23 \%$ (8/10 mice) were further quantitated amongst mice in 24 weeks of $3 \mathrm{MC}$ treatment (Fig. 6B, lower panel). Moreover, Ki67 expression patterns in the whole tissue proteins were fairly high (Fig. 6A, upper panel). Such a distinctively active functional status of the protein was absent amongst vehicle control and control mice during this interval.

\section{Chronic 3MC treatment induced COX2 enabled IAP activations}

To assess the strength of this prosurvival signaling in overriding apoptotic cues, the disposition of XIAP and survivin was analyzed in the cervical tissues of $3 \mathrm{MC}$-treated mice. Western blot results, as shown in Fig. 7A, clearly indicated the rising patterns in the protein expression of XIAP and survivin in the mouse cervical tissue lysates at the treatment interims. Particularly, for XIAP, a hike in expression was attained at the 16th week of $3 \mathrm{MC}$ treatment. Survivin, on the contrary, was not as high as XIAP, while in relation to control and vehicle control mice, the expression profiles were considerably high.

The IHC results, as portrayed in Fig. 7B, revealed the presence of functional XIAP and survivin proteins in the cellular cytoplasm of cervical tissue sections specifically obtained from 3MC-treated mice at the 16th and 24th weeks. Respective positive staining intensities for XIAP scored approximately 75.25\% ( 7/10 mice) and $78.625 \%$ ( 8/10 mice) among these respective batches. Similarly, the cytoplasm was comparatively less stained (16 weeks: 55\%; 5/10 mice, 24 weeks: 59.98\%; 6/10 mice) for survivin. Again, XIAP $(r=0.8570 \& r=$ $0.9010 ; p<0.005)$ and survivin $(r=0.8933 \& r=0.9271 ; p<0.005)$ expression was strongly positively correlated with the activity and expression of COX2 in the 3MC-treated mice (Table 3A). The absence of these findings in the vehicle control and control animals was imperative of the involvement of the NFKB/COX2/IAP axis in the development of cervical neoplasia in 3MC-treated mice.

\section{COX2 activation immortalized cervical cells by facilitating Ki67 and PCNA expression}

The spatial distribution of proliferative antigens Ki67 and PCNA was studied by IHC to assess the proliferative potential of the cervical epithelium as a culmination of NFKB/COX2/IAP functions. Positive staining of cellular nuclei in all the differential cervical epithelial layers was noted amongst the tissue sections of mice subjected to $3 \mathrm{MC}$ treatment for 16 and 24 weeks or more (Fig. 8A). These patterns were delimited only to the undifferentiated proliferative basal epithelial cell layers of the control and vehicle control groups. Clear manifestations of uniform staining for Ki67 and PCNA of all cells in the cervical epithelium were scored and illustrated comparatively in Fig. 8B. 


\section{Inflammation-induced systemic stress generates free radicals by disrupting antioxidant defence mechanisms}

To further determine the systemic impact of chronic cervical 3MC treatment in mice, ROS and RNS levels were quantified in blood leukocytes and peritoneal macrophages. Relative interpretations of these findings were undertaken with respect to iNOS and the total antioxidant enzyme activities. A significant increase in ROS levels was noted in 3MC-treated mice from the 16th week onwards (Fig. 9A). These observations were consistent with those of RNS levels among these same mouse groups (Fig. 9B). Nitrite generation was documented to rise from the 16 th week $(3.813 \pm 0.00686 \mu \mathrm{M} / 106 \mathrm{cells} / \mathrm{min})$, which was found to attain a peak after 30 weeks of $3 \mathrm{MC}$ treatment. Both of these findings coincided with the activity trends of iNOS, as shown in Fig. 9C, where the enzyme activity was found to produce citrulline of approximately $11.89 \pm 0.15311 \%$ in the 16 th week specifically. These parameters were found to be subletting each other for promoting systemic stress, as revealed by their significantly strong positive correlations (Table 3B).

All these findings necessitated examining the activities of the total antioxidant enzyme capacities. A graphical overview clearly depicted a gradual rise in free radical scavenging activity up to the 12th and 16th weeks of treatment (Fig. 9D), which subsequently declined by 24 and 30 weeks. Relatively, in the vehicle control groups, the free radical scavengers were found to function properly with exposure to PET, similar to the control group. The subtly increasing trend of antioxidant enzyme activities holistically helped quench the PET-generated free radicals, which went unquenched in the carcinogen-treated groups.

\section{Cervical inflammation imposes systemic genotoxic stress, eventually deregulating key tumor suppressor proteins}

To ascertain the genotoxic profile upon 3MC exposure-mediated inflammatory stress, a comet assay was performed with leukocytes isolated from mouse blood of all three groups. Fluorescence microscopy images revealed the distribution patterns of damaged DNA in terms of DNA migration (comet formation) among different groups (Fig. 10Ai-xv). The results upheld the appearance of distinct DNA tails among the 3MC-treated groups with incremental time periods. Among the PET-treated mice, the presence of such damage was indistinct, similar to that of the untreated animals. The concomitant rise in the comet tail moment as calculated by KOMET software is represented graphically in Fig. 10B. The results were indicative of the impact of free radical-mediated stress on DNA (Table $3 \mathrm{~B})$.

Blood-bearing leukocytes harbouring damaged DNA also drain into the cervical region, which was eventually transformed by hiked COX2 activities. Continual inflammation driving changes mediated by COX2 accompanied a subsequent reduction in the expression profiles of tumor suppressors at the protein level in the mouse cervical tissue extracts. Western blot data, as depicted in Fig. 10C, are imperative of the gradual decrease in the protein expression of p53, p21 and Rb, specifically at and after 16 weeks of 3MC treatment. Unstable expression profiles of acetylated p53 (Lys373), the active form of the protein, further supported this observation. These inferences bridge the impact of inflamogenic stress induced in the cervix with the role of simultaneously induced systemic stress in favouring cervical carcinogenesis in this study.

\section{Discussion}


Despite therapeutic advancements, a higher expression status of COX2 in cervical cancer surmounts therapy resistance followed by disease relapse. Traditionally being an HPV-mediated cancer, the viral oncoproteins E5, E6 and E7 were found to turn on 'amphiregulin', the COX2 activator, either in a ligand-dependent or ligandindependent manner via MAPK or PI3K/Akt pathways $[42,43]$. Consistent with HPV-mediated cervical cancers, the present model also exhibited escalated COX2 kinetics. Hence, the role of COX2 as an orchestrator of dysregulated inflammation in inducing cervical neoplastic changes upon chronic treatment with $3 \mathrm{MC}$ is well highlighted in this study. A concomitant rise in the expression and activity of COX2 accelerated the expression of prosurvival molecules such as NFKB (p50/p65), GM-CSF1, XIAP and survivin within the mouse cervix tissue with prolonged treatment duration. This clearly annotated the presence of a 'positive feedback loop' of prosurvival signaling molecules, which paved the way for cervical neoplasia (Table 3A).

The current results, along with previous laboratory findings of elevated expression and activities of the inflammatory cytokines IL6 and IL8 in the cervical tumor microenvironment of 3MC-treated mice favoring carcinogenic progression, were in accordance with the study of Li et al. (2018), wherein IL6, IL8 and COX2 triggered each other to induce carcinogenesis [6]. The present study confirmed the localization of the COX2 protein in the nucleus and cytoplasm of cervical tissues obtained from mice undergoing $3 \mathrm{MC}$ treatment, predominantly for 16 weeks, 24 weeks and onwards. This hinted towards the prevalence of upregulated COX2 dynamics in the cervix. Quantitative estimation of COX2 activity also reflected a stimulated trend in enzyme kinetics. Such an inference enabled identification of COX2 as the protagonist molecule directing this episode of 'inflammogenesis of cervical cancer'.

Further experimentation revealed convenient regulation by COX2 in the generation of a molecular interactome involving erratically expressed tumor suppressor proteins (p53, p21 and Rb) and upregulated prosurvival proteins, which primarily included NFKB, XIAP and survivin, in 3MC-driven cervical carcinogenesis. This eventually impacted the transformation of the reproductive organ anatomy, cytopathology, histopathology and biochemistry of the carcinogen-treated mice. COX2 and p53 are antagonistic in function because the latter is known to positively regulate 'thrombospondin-1', which directly inhibits angiogenesis by shutting down the angiogenic effector molecule VEGF $[28,29]$. Hypoxia-induced functional facilitation of p53 is a common occurrence within a tumor lump, alongside activation of NFKB and COX2. However, during carcinogenic discourse, growth aiding cues received in terms of hiked iNOS activity were reported to encourage NFKB and COX2 to override p53 action to progress with neoplasia [44, 45]. In agreement with these previously published reports, the tumor obtained after 24 weeks of carcinogen treatment in the present study also exhibited high COX2 and NFKB expression in the tumor core with concomitantly high COX2 activity. IHC results fostering nuclear accumulation of the p65 and p50 subunits of NFKB were indicative of its active functional status. Nonetheless, an eventual decline in p53 correspondingly accompanied by a rise in IAPs with time was an alibi to COX2, being the silent umpire of the interplay between these promoters of carcinogenesis.

Another interesting observation of the present study was the formation of an enlarged spleen (splenomegaly), which was specifically observed in animals at the 16th week of $3 \mathrm{MC}$ treatment and onwards. Documentation of the cumulative experimental findings unveiled the treatment period of the 16th week as the 'crucial-interim' for the development of invasive cancer among these mice. An enlarged spleen showed altered histopathology, which was characterized by the presence of eosinophil inflitrations and an enhanced number of 'germinal centres', the hubs that nourish and train naïve blood leukocytes to become immunologically competent [46]. 
Continual carcinogenic treatment in mice for 30 weeks caused outbursts of free radicals to mediate systemic stress, as evident from escalated iNOS activity, indiscriminately increased ROS and RNS levels, which conjugatively compromised the scavenging capacity of the antioxidant enzymes. The impact of these multiple oxidative hits was apparent in the form of concurrent damage incurred upon leukocyte DNA, as observed from the comet assay (Table 3B). As a PAH, 3MC becomes potentiated as a carcinogen only after biotransformation. Thus, its effect on systemic parameters in the long run was inevitable. Moreover, COX2 was also reported to promote invasion of cervical cancer cells into lymphoid organs and blood vasculature [47]. In all probability, causation of splenomegaly was also one of the attributions of COX2 in this experimental model.

The cervix is under constant immune surveillance since it is always patrolled by leukocytes, specifically eosinophils, in addition to having an acidic niche. Any shift or drift in the cervical leucocyte subpopulation is therefore alarming. In this study, a shoot-up of neutrophils with altered morphologies accompanied by monocytes gradually replaced the eosinophilic multitude of the mouse cervix at 16 weeks of $3 \mathrm{MC}$ treatment, which persisted with time to quench the carcinogenic assault. These inflamogenic mediators seem to have drained into the cervix following seepage from an enlarged spleen, as relentless leucopoiesis was reported to render splenomegaly [48]. Molecular insights further evinced a parallel rise in GM-CSF1, the key functional neutrophil differentiator. Evidentially, COX2 in this study acted as a driver of cervical inflammatory events, which eventually amplified the entire system of the animals.

XIAP and survivin are vital prosurvival molecules that migrate from the nucleus to the cytoplasm to become functionally active. Cytosolic IAPs bind to caspase enzymes, cellular executioners, thereby rendering them inactive [49]. In the present study, appreciable cytosolic dislocation of the respective IAPs on and after the 16th week of treatment span was obvious. This was confirmed by collateral nuclear accumulation of the proliferative antigens Ki67 and PCNA. As comprehendible from immunostaining of cervix tissues for Ki67 and PCNA (IHC results), the immortalized cells of the cervix were found to express these proliferative antigens, which subsequently disbursed from the proliferative basal layer to the rest of the differential cervical epithelial layers. COX2-mediated activation of prosurvival effectors for boosting malignant cervical transformations could be vividly envisioned from this present finding. Upregulated COX2 with all its allies tailored the never-ending saga of $3 \mathrm{MC}$-induced carcinogenic inflammation to enable the development of cervical carcinoma. The overall findings are schematically represented in Fig. 11.

\section{Conclusion}

The in vivo model established here flaunts a microenvironment that has upregulated prosurvival molecules under the command of COX2. Thus, it can be treated as a model to address issues of therapy resistance that stymy cervical cancer treatment. This referral model sheds paramount light upon ways to target COX2 and its several unknown effectors as prognostic and diagnostic biomarkers for planning a better treatment rationale.

\section{Declarations}

\section{AUTHOR CONTRIBUTION}

Elizabeth Mahapatra has predominantly acquired all the data, analysed them to design the concept for this paper and has accordingly composed the manuscript with assistance from Souvick Biswas and Salini Das. 
Sutapa Mukherjee designed the project work and critically checked the manuscript.

Madhumita Roy has checked through the manuscript.

\section{FUNDING}

The authors thankfully acknowledge the Ministry of Health and Family Welfare, Govt. of India for providing financial aid through Intramural Project Funding earned by Dr. Sutapa Mukherjee (Senior Scientific Officer-I, Dept. of Environmental Carcinogenesis \& Toxicology, CNCl, Kolkata, India).

\section{ACKNOWLEDGEMENT}

The authors are indebted to Director, $\mathrm{CNCl}$ for providing infrastructural facilities. The authors heartily thank Dr. Debasish Chakraborty (Assistant Professor, Dept. of Pathology, IPGMER, Kolkata, India) for helping them analyze the histology results and Dr. Abhijit Rakshit (Head of Department, Dept. of Animal Care and Maintenance, $\mathrm{CNCl}$, Kolkata, India) for his invaluable inputs in animal segregation and batching. With special mention, the authors humbly acknowledge the contribution of Dr. Chinmay Kumar Panda (Ex-Head of Department, Dept. of Oncogene Regulation Unit, $\mathrm{CNCl}$, Kolkata, India) for guidance in identification of the correct time period of this experimental study.

\section{DATA AVAILABILITY}

All the datasets displayed in the current study are available from the corresponding author on reasonable request.

\section{CODE AVAILABILITY}

There is no code available.

\section{Conflict of Interest.}

The authors declare that they have no known conflicts of interest.

\section{Ethics Approval.}

All animal experiments were carried out in accordance with IAEC ethical norms. Mice were procured only after ethical clearance (IAEC Proposal No\# IAEC-1774/SM-1/2018/7) for the concerned project.

\section{Consent to participate.}


All authors have wilfully participated in the concerned work following which they have given complete consent for publication.

\section{Consent for Publications.}

All authors have given their consent for this publication.

\section{References}

1. Cui, Y., X. O. Shu, H. L. Li, G. Yang, W. Wen, Y. T. Gao, Q. Cai, N. Rothman, H. Y. Yin, Q. Lan, Y. B. Xiang, and W. Zheng. 2017. Prospective study of urinary prostaglandin E2 metabolite and pancreatic cancer risk. Int J Cancer 141: 2423-2429.

2. Hashemi Goradel, N., M. Najafi, E. Salehi, B. Farhood, and K. Mortezaee. 2019. Cyclooxygenase-2 in cancer: A review. J Cell Physiol. 234: 5683-5699.

3. Kim, E. H., H. K. Na, D. H. Kim, S. A. Park, H. N. Kim, N. Y. Song, and Y. J. Surh. 2008. 15-Deoxy-Delta12, 14prostaglandin $\mathrm{J} 2$ induces COX-2 expression through Akt-driven AP-1 activation in human breast cancer cells: a potential role of ROS. Carcinogenesis. 29: 688-695.

4. Lang, S., H. Busch, M. Boerries, T. Brummer, S. Timme, S. Lassmann, K. Aktories, and G. Schmidt. 2017. Specific role of RhoC in tumor invasion and metastasis. Oncotarget 8: 87364-87378.

5. Wang, D., F. G. Buchanan, H. Wang, S. K. Dey, and R. N. DuBois. 2005. Prostaglandin E2 enhances intestinal adenoma growth via activation of the Ras-mitogen-activated protein kinase cascade. Cancer Res 65: $1822-1829$.

6. Li, N. N., X. S. Meng, Y. R. Bao, S. Wang, and T. J. Li. 2018. Evidence for the Involvement of COX-2/VEGF and PTEN/PI3K/AKT Pathway the Mechanism of Oroxin B Treated Liver Cancer. Pharmacogn Mag 14: 207213.

7. Yanni, S. E., G. W. McCollum, and J. S. Penn. 2010. Genetic deletion of COX-2 diminishes VEGF production in mouse retinal Müller cells. Exp Eye Res 91: 34-41.

8. Konstantinopoulos, P. A., G. P. Vandoros, G. Sotiropoulou-Bonikou, A. Kominea, and A. G. Papavassiliou. 2007. NF-kappaB/PPAR gamma and/or AP-1/PPAR gamma 'on/off' switches and induction of CBP in colon adenocarcinomas: correlation with COX-2 expression. Int J Colorectal Dis 22: 57-68.

9. Szweda, M., A. Rychlik, I. Babińska, and A. Pomianowski. 2019. Significance of Cyclooxygenase-2 in Oncogenesis. J Vet Res. 63: 215-224.

10. Tsatsanis, C., A. Androulidaki, M. Venihaki, and A. N. Margioris. 2006. Signalling networks regulating cyclooxygenase-2. Int J Biochem Cell Biol 38: 1654-1661.

11. Parida, S., and M. Mandal. 2014. Inflammation induced by human papillomavirus in cervical cancer and its implication in prevention. Eur J Cancer Prev. 23: 432-448.

12. Müller-Decker, K. 2011. Cyclooxygenase-dependent signaling is causally linked to non-melanoma skin carcinogenesis: pharmacological, genetic, and clinical evidence. Cancer and Metastasis Reviews 30: 343361. 
13. Moon, H., A. C. White, and A. D. Borowsky. 2020. New insights into the functions of Cox-2 in skin and esophageal malignancies. Exp Mol Med. 52: 538-547.

14. Simões, M. C. F., J. J. S. Sousa, and A. A. C. C. Pais. 2015. Skin cancer and new treatment perspectives: a review. Cancer Letters 357: 8-42.

15. Siegrist, K. J., D. Romo, B. L. Upham, M. Armstrong, K. Quinn, L. Vanderlinden, R. S. Osgood, K. Velmurugan, M. Elie, J. Manke, D. Reinhold, N. Reisdorph, L. Saba, and A. K. Bauer. 2019. Early Mechanistic Events Induced by Low Molecular Weight Polycyclic Aromatic Hydrocarbons in Mouse Lung Epithelial Cells: A Role for Eicosanoid Signaling. Toxicol Sci 169: 180-193.

16. Asproni, P., M. Vignoli, S. Cancedda, F. Millanta, R. Terragni, and A. Poli. 2014. Immunohistochemical expression of cyclooxygenase-2 in normal, hyperplastic and neoplastic canine lymphoid tissues. J Comp Pathol. 151: 35-41.

17. Hsum, Y. W., W. T. Yew, P. L. Hong, K. K. Soo, L. S. Hoon, Y. C. Chieng, and L. Y. Mooi. 2011. Cancer chemopreventive activity of maslinic acid: suppression of COX-2 expression and inhibition of NF-KB and AP-1 activation in Raji cells. Planta Medica 77: 152-157.

18. Bandyopadhyay, R., U. Chatterjee, S. K. Mondal, D. Nag, and S. K. Sinha. 2011. A study on expression pattern of cyclooxygenase-2 in carcinoma of cervix. Indian J Pathol Microbiol. 54: 695-699.

19. Bengi, G., D. Keles, Ö. Topalak, M. Yalçin, R. Kiyak, and G. Oktay. 2015. Expressions of TIMP-1, COX-2 and MMP-7 in Colon Polyp and Colon Cancer. Euroasian J Hepatogastroenterol. 5: 74-79.

20. Hidalgo-Estévez, A. M., K. Stamatakis, M. Jiménez-Martínez, R. López-Pérez, and M. Fresno. 2020. Cyclooxygenase 2-Regulated Genes an Alternative Avenue to the Development of New Therapeutic Drugs for Colorectal Cancer. Frontiers in Pharmacology 11: 533.

21. Jessen, C., J. K. C. Kreß, A. Baluapuri, A. Hufnagel, W. Schmitz, S. Kneitz, S. Roth, A. Marquardt, S. Appenzeller, C. P. Ade, V. Glutsch, M. Wobser, J. P. Friedmann- Angeli, L. Mosteo, C. R. Goding, B. Schilling, E. Geissinger, E. Wolf, and S. Meierjohann. 2020. The transcription factor NRF2 enhances melanoma malignancy by blocking differentiation and inducing COX2 expression. Oncogene. 39: 6841-6855.

22. Liu, F., W. Q. Wei, R. T. Cormier, S. T. Zhang, Y. L. Qiao, X. Q. Li, S. T. Zhu, Y. C. Zhai, X. X. Peng, Y. X. Yan, L. J. Wu, D. He, and Y. He. 2014. Association of single nucleotide polymorphisms in the prostaglandinendoperoxide synthase 2 (PTGS2) and phospholipase Aâ\& group IIA (PLA2G2A) genes with susceptibility to esophageal squamous cell carcinoma. Asian Pac J Cancer Prev 15: 1797-1802.

23. Fodor, D., I. Jung, S. Turdean, C. Satala, and S. Gurzu. 2019. Angiogenesis of hepatocellular carcinoma: An immunohistochemistry study. World J Hepatol 11: 294-304.

24. Ye, Y., X. Wang, U. Jeschke, and V. von Schönfeldt. 2020. COX-2-PGE2-EPs in gynecological cancers. Arch Gynecol Obstet. 301: 1365-1375.

25. Hill, R., Y. Li, L. M. Tran, S. Dry, J. H. Calvopina, A. Garcia, C. Kim, Y. Wang, T. R. Donahue, H. R. Herschman, and H. Wu. 2011. Cell intrinsic role of COX-2 in pancreatic cancer development. Mol Cancer Ther 11: 21272137.

26. Shi, G., D. Li, J. Fu, Y. Sun, Y. Li, R. Qu, X. Jin, and D. Li. 2015. Upregulation of cyclooxygenase-2 is associated with activation of the alternative nuclear factor kappa B signaling pathway in colonic adenocarcinoma. Am J Transl Res. 7: 1612-1620. 
27. Mortezaee, K., E. Salehi, H. Mirtavoos-Mahyari, E. Motevaseli, M. Najafi, B. Farhood, R. J. Rosengren, and A. Sahebkar. 2019. Mechanisms of apoptosis modulation by curcumin: Implications for cancer therapy. J Cell Physiol. 234: 12537-12550.

28. Janani, S. K., S P, D., R, S., Sai Surya, and N. U. Chenmala, K. 2021. Guardian of genome on the tract: Wild type p53-mdm2 complex inhibition in healing the breast cancer. Gene. 786: 145616.

29. Tong, X., S. Mirzoeva, D. Veliceasa, B. B. Bridgeman, P. Fitchev, M. L. Cornwell, S. E. Crawford, J. C. Pelling, and O. V. Volpert. 2014. Chemopreventive apigenin controls UVB-induced cutaneous proliferation and angiogenesis through HuR and thrombospondin-1. Oncotarget. 5: 11413-11427.

30. Kaczmarzyk, T., K. Kisielowski, R. Koszowski, M. Rynkiewicz, E. Gawełek, K. Babiuch, A. Bednarczyk, and B. Drozdzowska. 2018. Investigation of clinicopathological parameters and expression of COX-2, bcl-2, PCNA, and p53 in primary and recurrent sporadic odontogenic keratocysts. Clin Oral Investig. 22: 3097-3106.

31. Mortezaee, K., E. Salehi, H. Mirtavoos-Mahyari, E. Motevaseli, M. Najafi, B. Farhood, R. J. Rosengren, and A. Sahebkar. 2019. Mechanisms of apoptosis modulation by curcumin: Implications for cancer therapy. J Cell Physiol 234: 12537-12550.

32. Stasinopoulos, I., T. Shah, M. F. Penet, B. Krishnamachary, and Z. M. Bhujwalla. 2013. COX- 2 in cancer: Gordian knot or Achilles heel? Frontiers in Pharmacology 4: 34.

33. McClain-Caldwell, I., L. Vitale-Cross, B. Mayer, M. Krepuska, M. Boyajian, V. Myneni, D. Martin, GENOMICS AND COMPUTATIONAL BIOLOGY CORE, K. Marko, K. Nemeth, and E. Mezey. 2018. Immunogenic potential of human bone marrow mesenchymal stromal cells is enhanced by hyperthermia. Cytotherapy. 20: 14371444.

34. Ylöstalo, J. H., T. J. Bartosh, K. Coble, and D. J. Prockop. 2012. Human mesenchymal stem/stromal cells cultured as spheroids are self-activated to produce prostaglandin E2 that directs stimulated macrophages into an anti-inflammatory phenotype. Stem Cells 30: 2283-2296.

35. Zhao, Y., T. Wu, S. Shao, B. Shi, and Y. Zhao. 2015. Phenotype, development, and biological function of myeloid-derived suppressor cells. Oncoimmunology 5 (2): e1004983.

36. Mc Clintock, M. K. 1981. Social Control of the Ovarian Cycle and the Function of Estrous Synchrony. Amer Zool 21: 243.

37. Mahapatra, E., S. Biswas, M. Roy, and S. Mukherjee. 2020. Inflammation: A protagonist in development of carcinogen induced cervical cancer in mice. Indian Journal of Biochemistry \& Biophysics 57: 158-166.

38. Basu, M., S. Ghosh, A. Roychowdhury, S. Samadder, P. Das, S. Addya, A. Roy, D. K. Pal, S. Roychoudhury, A. Ghosh, and C. K. Panda. 2020. Integrative genomics and pathway analysis identified prevalent FA-BRCA pathway alterations in arsenic-associated urinary bladder carcinoma: Chronic arsenic accumulation in cancer tissues hampers the FA-BRCA pathway. Genomics 112: 5055-5065.

39. Sinha, D., S. Roy, and M. Roy. 2010. Antioxidant potential of tea reduces arsenite induced oxidative stress in Swiss albino mice. Food Chem Toxicol 48: 1032-1039.

40. Mahapatra, E., D. Dasgupta, N. Bhattacharya, S. Mitra, D. Banerjee, S. Goswami, N. Ghosh, A. Dey, and S. Chakraborty. 2017. Sustaining immunity during starvation in bivalve mollusc: A costly affair. Tissue and Cell 49: 239-248.

41. Biswas, J., S. Roy, S. Mukherjee, D. Sinha, and M. Roy. 2010. Indian spice curcumin may be an effective strategy to combat the genotoxicity of arsenic in Swiss albino mice. Asian Pacific J Cancer Prevention 11: 
239-249.

42. Kim, S. H., Y. S. Juhnn, S. Kang, S. W. Park, M. W. Sung, Y. J. Bang, and Y. S. Song. 2006. Human papillomavirus 16 E5 up-regulates the expression of vascular endothelial growth factor through the activation of epidermal growth factor receptor, MEK/ ERK1, 2 and PI3K/Akt. Cell Mol Life Sci 63: 930-938.

43. Luna, A. J., R. T. Sterk, A. M. Griego-Fisher, J. Y. Chung, K. L. Berggren, V. Bondu, P. Barraza-Flores, A. T. Cowan, G. N. Gan, E. Yilmaz, H. Cho, J. H. Kim, S. M. Hewitt, J. E. Bauman, and M. A. Ozbun, 2021. MEK/ERK signaling is a critical regulator of high-risk human papillomavirus oncogene expression revealing therapeutic targets for HPV-induced tumors. PLoS Pathog. 17, e1009216.

44. Parenti, A., L. Morbidelli, X. L. Cui, J. G. Douglas, J. D. Hood, H. R. Granger, F. Ledda, and M. Ziehe. 1998. Nitric oxide is an upstream signal of vascular endothelial growth factor-induced extracellular signalregulated kinase 1/2 activation in postcapillary endothelium. J Biol Chem. 273: 4220-4226.

45. Schmedtje, J. F., Y. S. Ji, W. L. Liu, R. N. DuBois, and M. S. Runge. 1997. Hypoxia induces cyclooxygenase-2 via NF-kappaB p65 transcription factor in human vascular endothelial cells. J Biol Chem 272: 601-608.

46. Stebegg, M., S. D. Kumar, A. Silva-Cayetano, V. R. Fonseca, M. A. Linterman, and L. Graca. 2018. Regulation of the Germinal Center Response. Front Immunol 9: 2469.

47. Hoellen, F., A. Waldmann, C. Banz-Jansen, A. Rody, M. Heide, F. Köster, J. Ribbat-Idel, C. Thorns, M. Gebhard, M. Oberländer, J. K. Habermann, and M. Thill. 2016. Expression of cyclooxygenase-2 in cervical cancer is associated with lymphovascular invasion. Oncol Lett 12: 2351-2356.

48. Lv, Y., W. Y. Lau, Y. Li, J. Deng, X. Han, X. Gong, N. Liu,. H. Wu. 2016. Hypersplenism: History and current status. Exp Ther Med 12: 2377-2382.

49. Shlezinger, N., M. Israeli, E. Mochly, L. Oren-Young, W. Zhu, and A. Sharon. 2016. Translocation from nuclei to cytoplasm is necessary for anti A-PCD activity and turnover of the Type II IAP BcBir1. Mol Microbio/99: 393-406.

\section{Tables}

Table 1

Animal Groups for Experimentation 


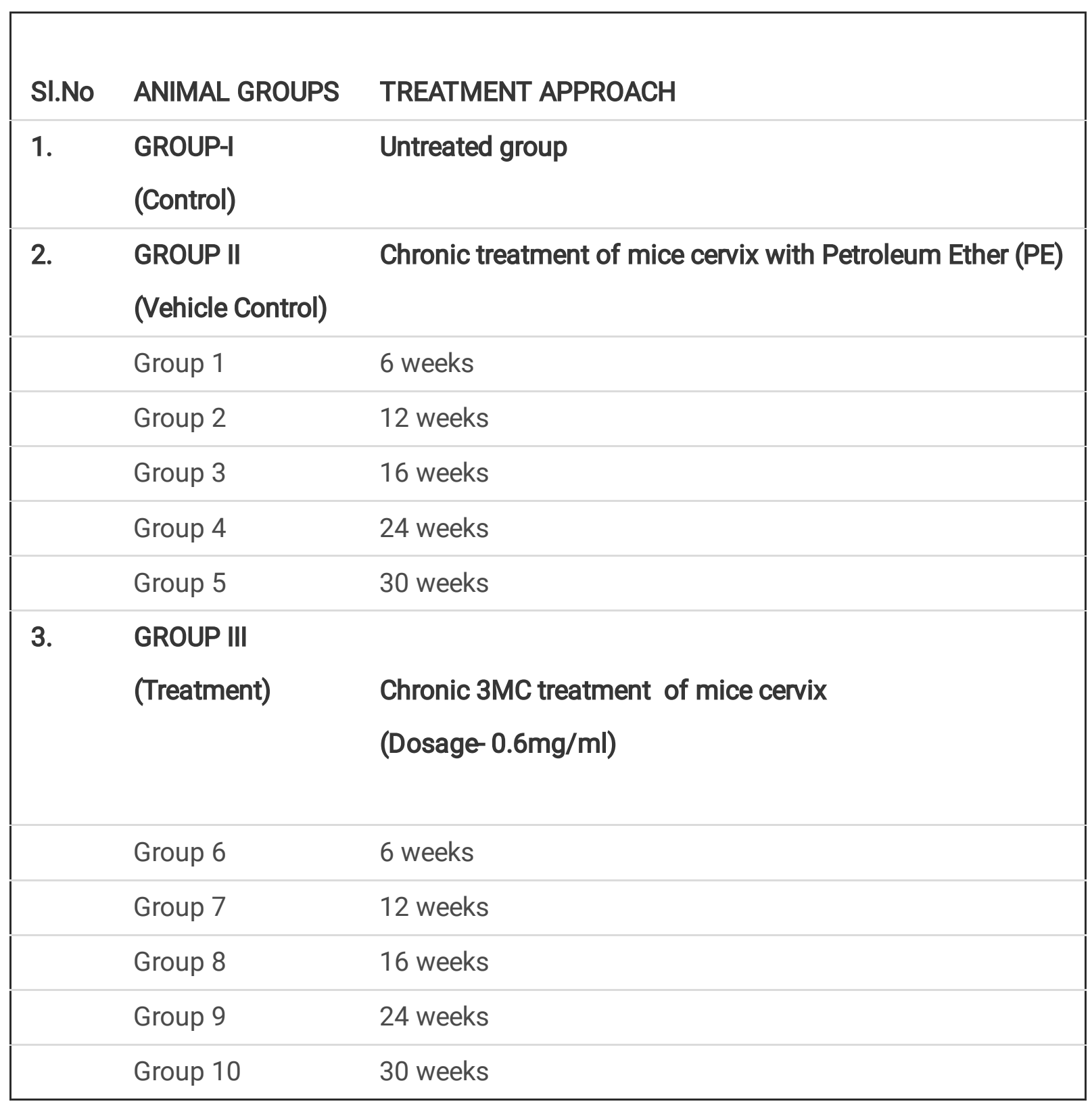

Table 2 A

Impact of 3MC treatment upon body weight of mice. 


\begin{tabular}{|c|c|c|c|c|c|c|}
\hline & \multicolumn{2}{|c|}{6 weeks } & \multirow{2}{*}{$\begin{array}{l}12 \text { weeks } \\
28 \pm 0.098\end{array}$} & \multirow{2}{*}{$\begin{array}{l}16 \text { weeks } \\
32 \pm 0.1702\end{array}$} & \multirow{2}{*}{$\begin{array}{l}24 \text { weeks } \\
33 \pm 0.16552\end{array}$} & \multirow{2}{*}{$\begin{array}{l}\text { 30weeks } \\
33.8 \pm 0.0954\end{array}$} \\
\hline \multirow{3}{*}{$\begin{array}{l}\text { ANIMAL } \\
\text { GROUPS } \\
\text { (Weight } \\
\text { in gms; } \\
\text { n=10) }\end{array}$} & $\begin{array}{l}\text { Group-I } \\
\text { (Control) }\end{array}$ & $25 \pm 0.2108$ & & & & \\
\hline & $\begin{array}{l}\text { Group- } \\
\text { II (Vehicle } \\
\text { Control) }\end{array}$ & $25.02 \pm 0.2213$ & $27 \pm 0.1658$ & $27.56 \pm 0.114$ & $31.11 \pm 0.0793$ & $32.7 \pm 0.0591$ \\
\hline & $\begin{array}{l}\text { Group-III } \\
\text { (Treatment) }\end{array}$ & $25.2 \pm 0.1079$ & $25.8 \pm 0.171$ & $24 \pm 0.0100$ & $29.1067 \pm 0.194$ & $35.4 \pm 0.09406$ \\
\hline
\end{tabular}

Table 2 B

Percentage (\%) of 3MC treated mice displaying cervical dysplasia and tumor stages.

\begin{tabular}{|lllllll|}
\hline & Normal & $\begin{array}{l}\text { Mild } \\
\text { Dysplasia }\end{array}$ & $\begin{array}{l}\text { Moderate } \\
\text { Dysplasia }\end{array}$ & $\begin{array}{l}\text { Invasive } \\
\text { Carcinoma }\end{array}$ & $\begin{array}{l}\text { Carcinoma } \\
\text { In Situ }\end{array}$ & $\begin{array}{l}\text { Anaplastic } \\
\text { Tumor }\end{array}$ \\
\hline $0^{\text {th }}$ week & $9 / 10$ & - & - & - & - & - \\
$(n=10)$ & $(90 \%)$ & & & & & \\
\hline $6^{\text {th }}$ week & $2 / 10$ & $8 / 10$ & - & - & - & - \\
$(n=10)$ & $(20 \%)$ & $(80 \%)$ & & & & \\
\hline $12^{\text {th }}$ week & $1 / 10$ & $2 / 10$ & $7 / 10$ & - & - & - \\
$(n=10)$ & $(10 \%)$ & $(20 \%)$ & $(70 \%)$ & & & - \\
\hline $16^{\text {th }}$ week & - & $1 / 10$ & $1 / 10$ & $8 / 10$ & - & - \\
$(n=10)$ & & $(10 \%)$ & $(10 \%)$ & $(80 \%)$ & & \\
\hline $24^{\text {th }}$ week & - & - & - & $2 / 10$ & $8 / 10$ & $(80 \%)$ \\
$(n=10)$ & & & & $(20 \%)$ & $(60 \%)$ \\
\hline $3^{\text {th }}$ week & - & - & - & $1 / 10$ & $3 / 10$ & $6 / 10$ \\
$(n=10)$ & & & & $(10 \%)$ & $(30 \%)$ & $(60 \%)$ \\
\hline
\end{tabular}

Table 3 (A)

Pearson's correlation coefficient among COX2 expression(COX2exp) profiles with COX2 activity, NFKB (p50), NFKB (p65), GM-CSF1, XIAP, survivin and p53 expression profiles of mice cervix subjected to chronic 3MC 
treatment for $0,6,12,16,24$ and 30 weeks.

\begin{tabular}{|lllllllll|}
\hline & $\begin{array}{l}\text { COX2 } \\
\text { exp }\end{array}$ & $\begin{array}{l}\text { COX2 } \\
\text { activity }\end{array}$ & $\begin{array}{l}\text { NFKB } \\
(\mathbf{p 5 0})\end{array}$ & $\begin{array}{l}\text { NFKB } \\
(\mathbf{p 6 5})\end{array}$ & $\begin{array}{l}\text { GM- } \\
\text { CSF1 }\end{array}$ & XIAP & Survivin & p53 \\
\hline COX2 exp & 1.000 & & & & & & \\
\hline $\begin{array}{l}\text { COX2 } \\
\text { activity }\end{array}$ & 0.9750 & 1.000 & & & & & \\
\hline NFKB & 0.9550 & 0.9444 & 1.000 & & & & \\
(p50) & & & & & & & \\
\hline NFKB & 0.9815 & 0.9280 & 0.9603 & 1.000 & & & \\
(p65) & & & & & & & \\
\hline GM-CSF1 & 0.9455 & 0.9109 & 0.8742 & 0.9305 & 1.000 & & \\
\hline XIAP & 0.9010 & 0.8570 & 0.9718 & 0.9491 & 0.8500 & 1.000 & & \\
\hline Survivin & 0.9271 & 0.8933 & 0.9849 & 0.9642 & 0.8617 & 0.9957 & 1.000 & \\
\hline p53 & -0.7901 & -0.7612 & -0.8807 & -0.912 & -0.7221 & -0.9200 & -0.9023 & 1.000 \\
\hline
\end{tabular}

Table 3(B)

Pearson's correlation coefficient among cervical COX2 activity and collateral systemic parametres ROS levels, RNS levels, iNOS activity and Comet Tail Moment(CTM) of mice subjected to chronic $3 M C$ treatment for $0,6,12$, 16,24 , and 30 weeks.

\begin{tabular}{|llllll|}
\hline & COX2 activity & ROS & RNS & iNOS & CTM \\
\hline COX2 activity & 1.000 & & & & \\
\hline ROS & 0.9872 & 1.000 & & & \\
\hline RNS & 0.9523 & 0.9537 & 1.000 & & \\
\hline iNOS & 0.9648 & 0.9446 & 0.9708 & 1.000 & \\
\hline CTM & 0.9606 & 0.9456 & 0.9652 & 0.9974 & 1.000 \\
\hline
\end{tabular}

\section{Figures}


(a)<smiles>Cc1ccc2cc3c(ccc4ccccc43)c3c2c1CC3</smiles><smiles>CCC(C)CC</smiles><smiles>CCCC</smiles>

3methylcholanthrene (3MC)

Petroleum Ether (PET)

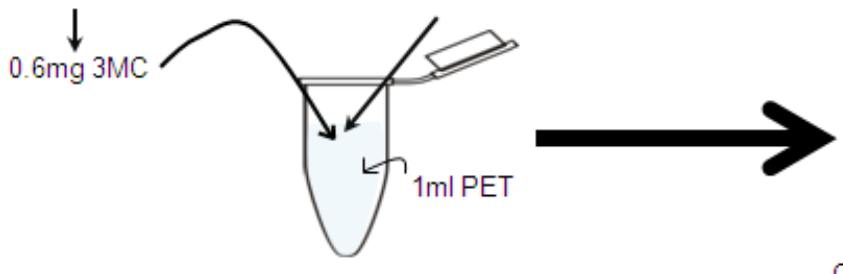

(b)

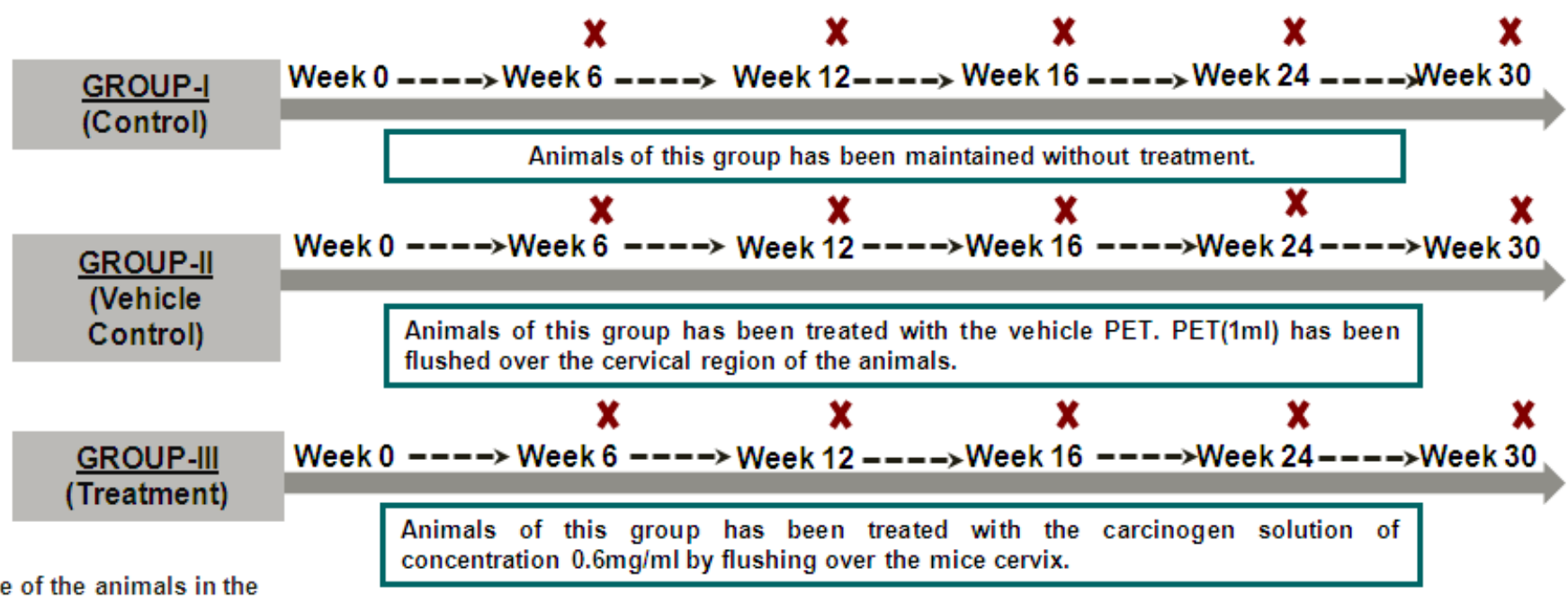

Sacrifice of the animals in the mentioned intermediate time period to track carcinogenic progression

Fig. 1.

\section{Figure 1}

Carcinogen preparation and experimental design (a) Schematic representation of the laboratory protocol adapted for preparing 3MC $(0.6 \mathrm{mg} / \mathrm{ml})$. (b) An experimental outline for the development of a cervical cancer model employing Swiss albino mice. 


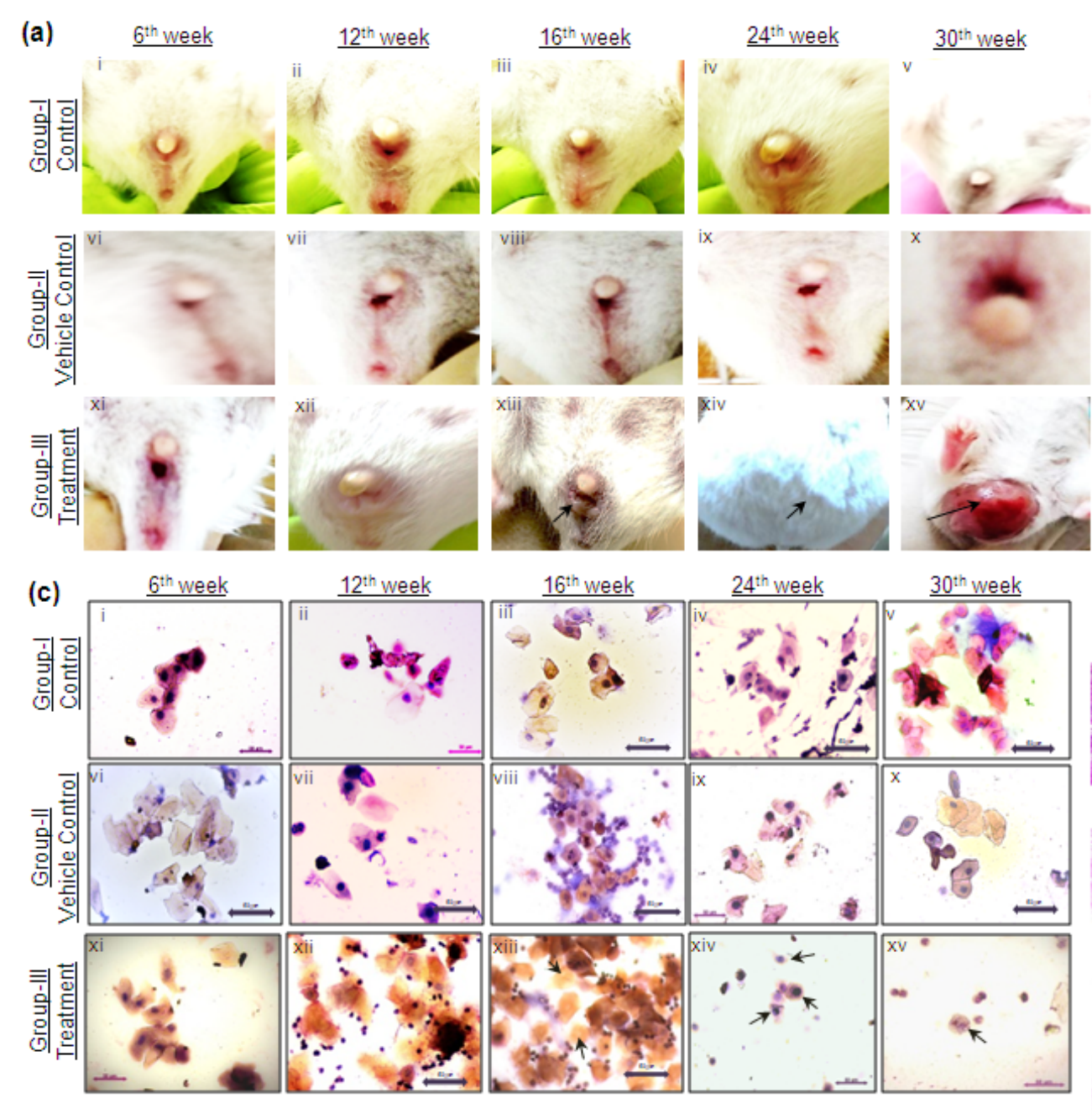

Fig. 2.
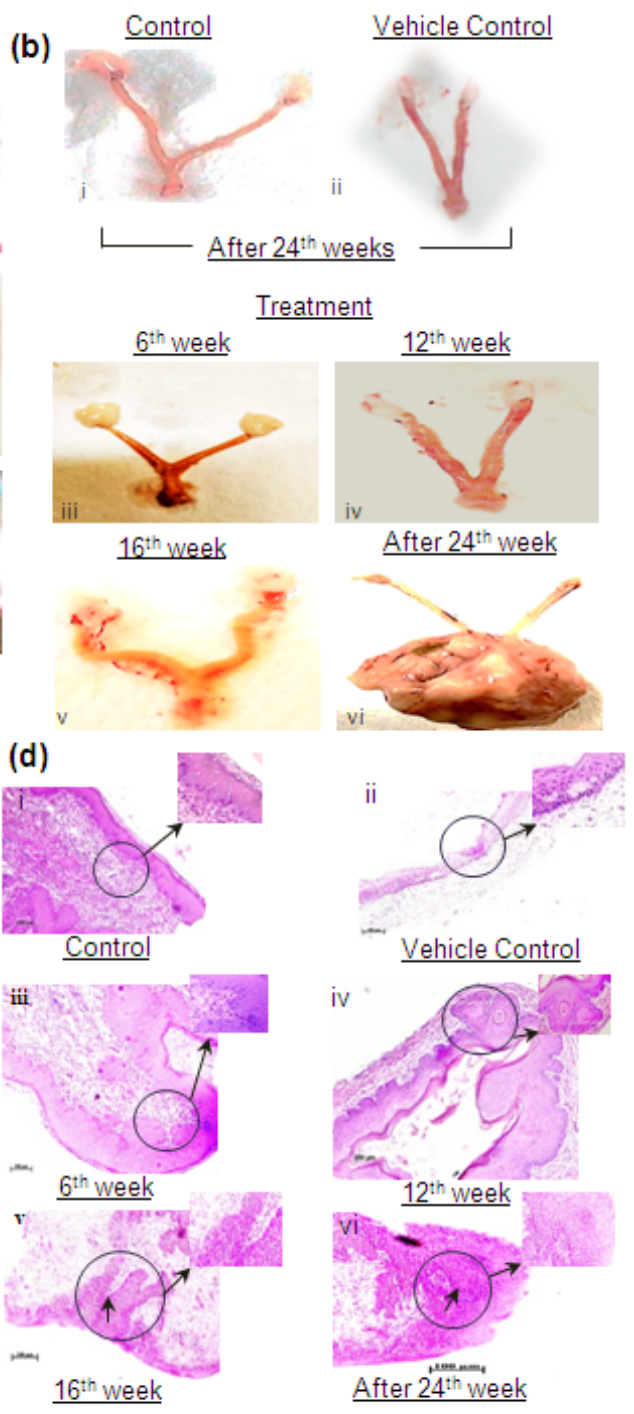

\section{Figure 2}

Understanding the progressive changes in mice upon $3 \mathrm{MC}$ treatment: Comparative images of external orifice, reproductive organ, cytopathological and histopathological features (a) Comparative pictorial representation of the external vaginal orifice among Group I, II and III mice wherein apparent disfigurement (arrow indicated) was obtained in 3MC treated groups, particularly at 16, 24 and 30 weeks (b) Reproductive systems of Groups I, II and III mice depicting the presence of palpable changes along with a discernible tumor (c) Illustrative micrographs (200X; Original magnifications x 10; scale bar: $50 \mu \mathrm{m}$ ) of Pap stained cervical exfoliated cells displaying cytopathological alterations as induced by $3 \mathrm{MC}$ and PET treatments in mice (d) Concomitant histopathological changes (indicated by arrows) evincing the presence of mild, moderate and severe (carcinoma in situ) dysplastic stages along with invasive cancer stages in 6th, 12th, 16th, 24th and 30th weeks of 3MC treatment. Main images are magnified up to 200X (original magnifications $\times 10$ ), with side-highlighted insets being magnified to $400 \mathrm{X}$. 
(a)
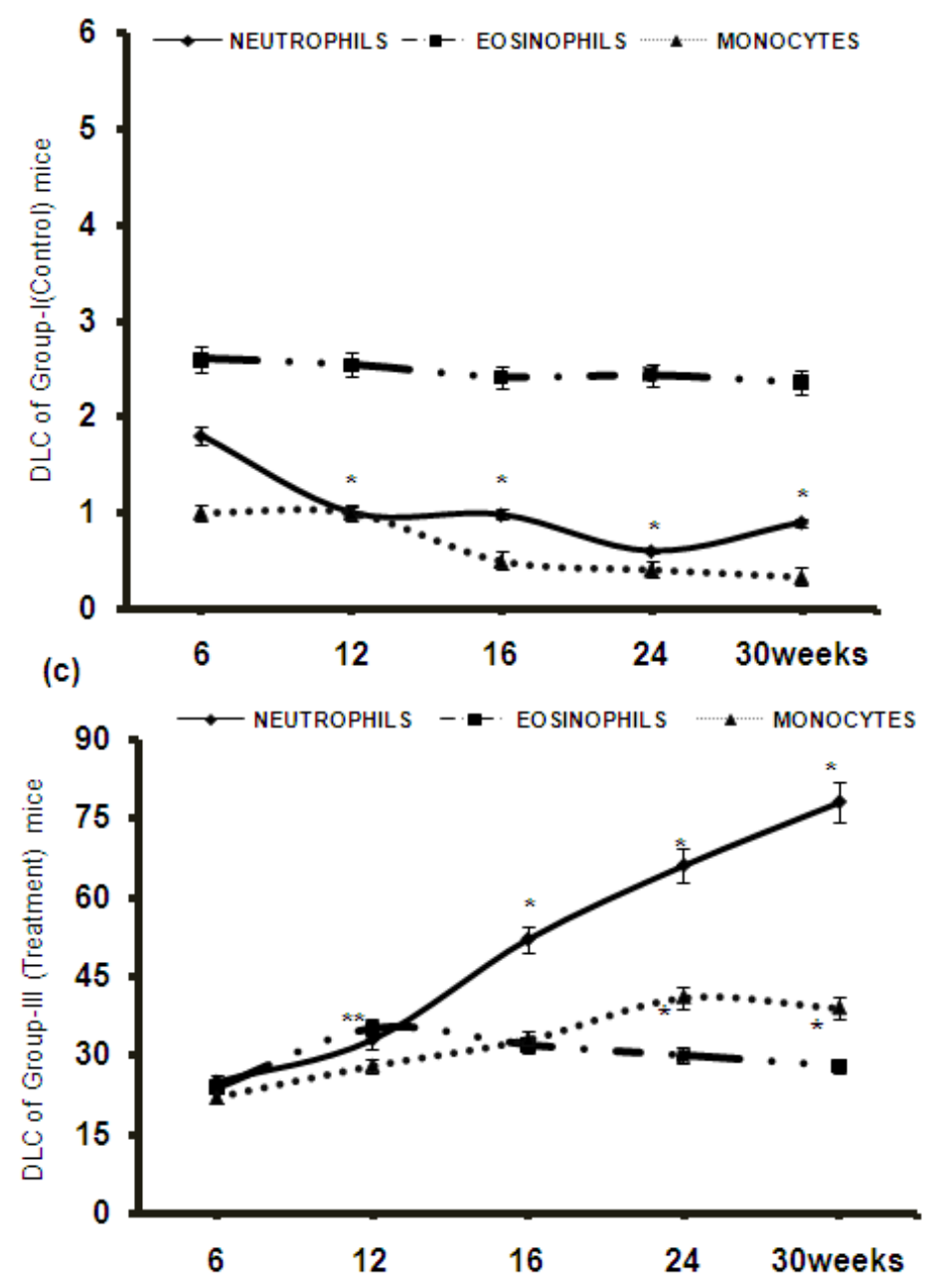

(b)
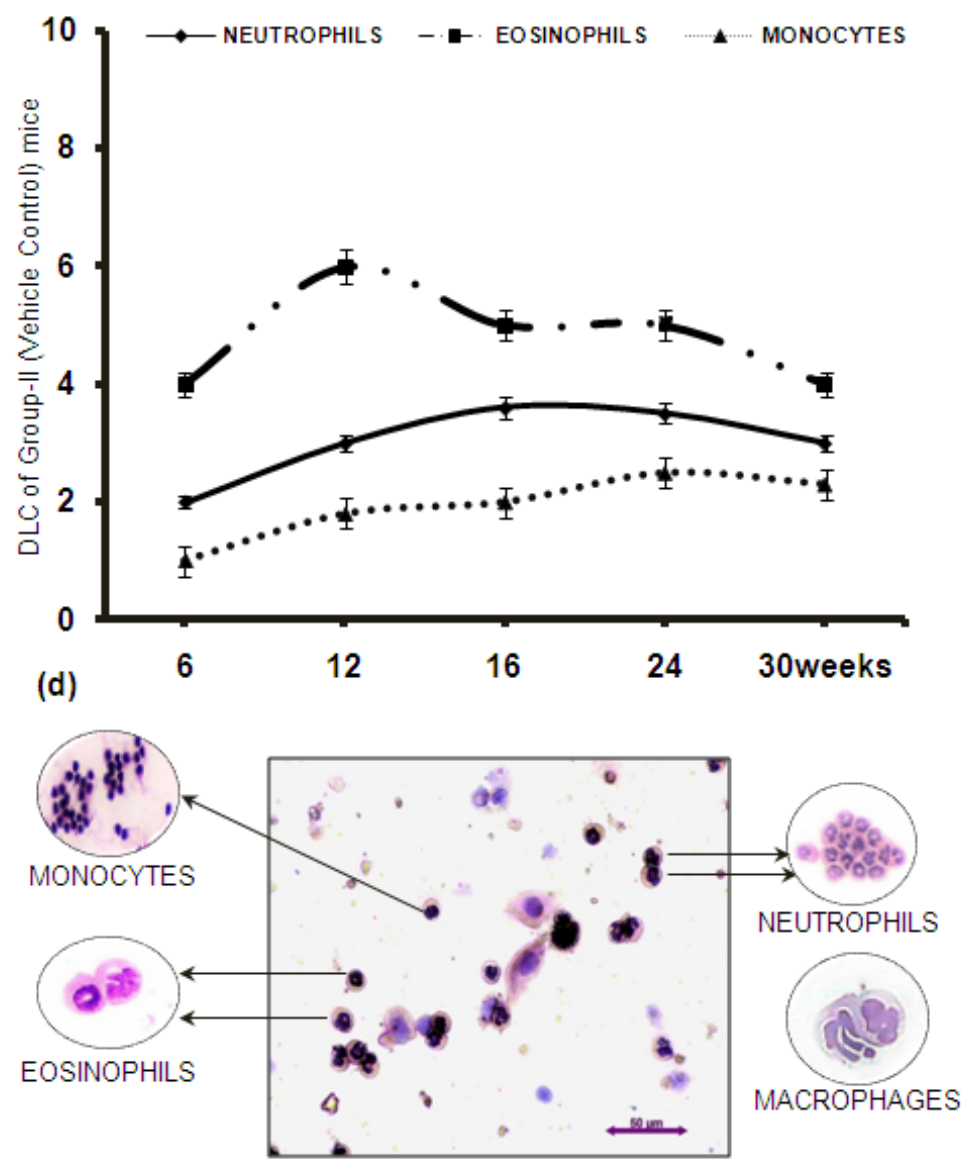

(e)

Fig. 3.

\section{Figure 3}

Differential cervical leukocytic flux during carcinogenic progression Comparative graphical representation of differential leukocyte count obtained in Pap-stained smears of (a) Group I, (b) Group II and (c) Group III mice. Data represented as Mean \pm S.D. was considered statistically significant $\left({ }^{*} p<0.005 /{ }^{*} p<0.01 ; N=10\right)$. (d) A representative micrographic snippet (200X; scale bar: $50 \mu \mathrm{m})$ of the cervix-invading leukocytes (eosinophils, neutrophils, monocytes and macrophages). (e) Specific light microscopic highlights of infiltrated morphologically diverse neutrophils in 3MC-treated animals. 


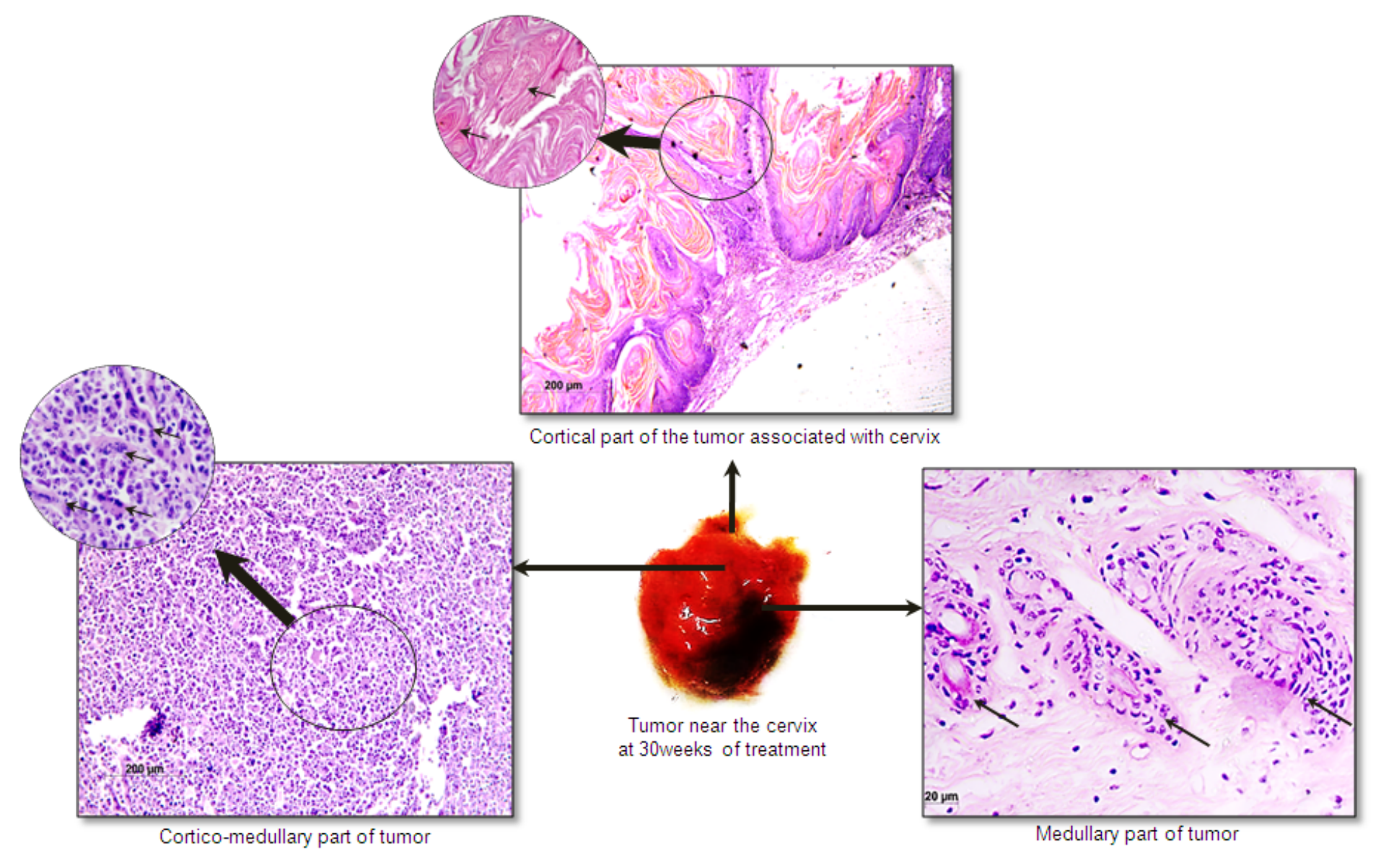

Fig. 4.

\section{Figure 4}

Histological characterization of cervical tumor Characteristic histological features in the sections (5 $\mu \mathrm{m}$ thick) from specific regions (cortex, cortico-medulla and medulla) of the cervical anaplastic tumor mass. Microscopic images were magnified up to 200x (original magnifications x 10; scale bar: $200 \mu \mathrm{m}$ ), while their respective insets are 400x (original magnifications x 10; scale bar: $20 \mu \mathrm{m}$ ) magnified. 


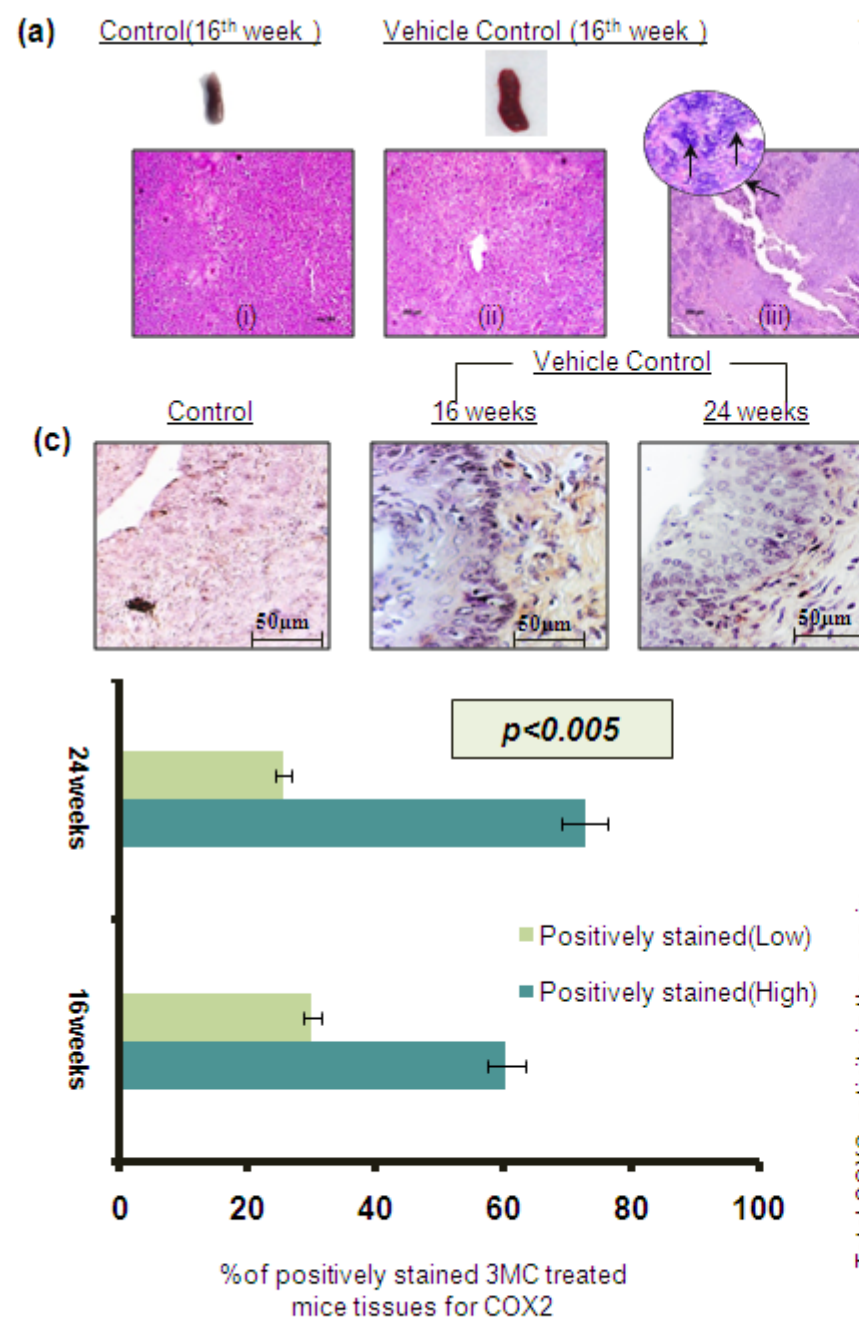

Fig. 5.
Treatment (16 th week)
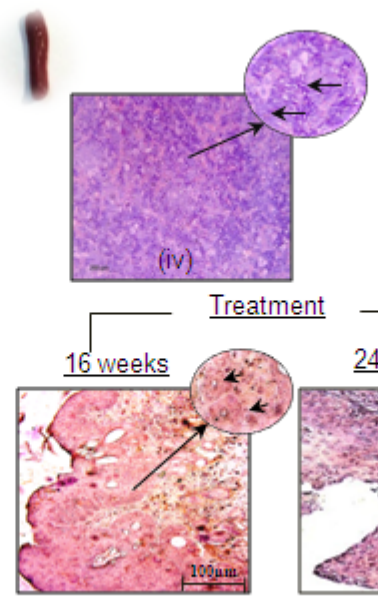

(d)

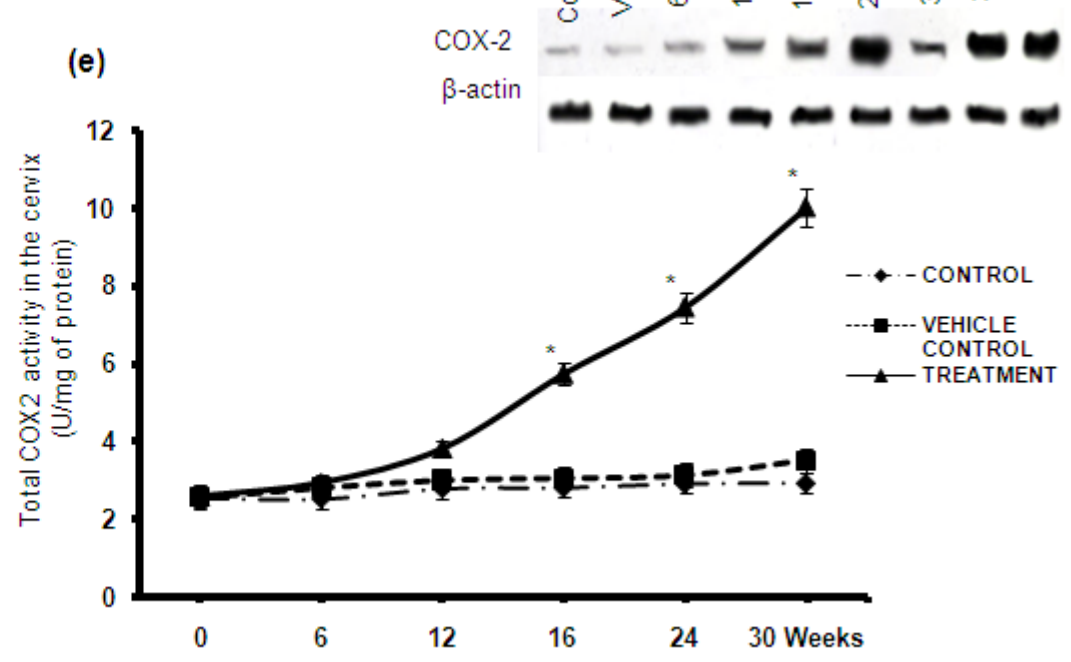

(b)

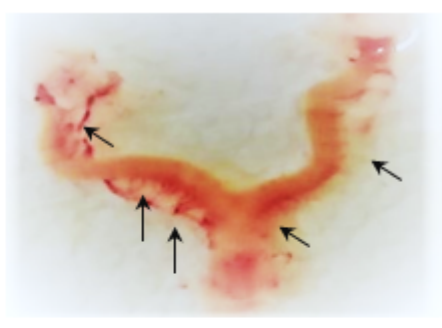

Reproductive system in the $16^{\text {th }}$ week
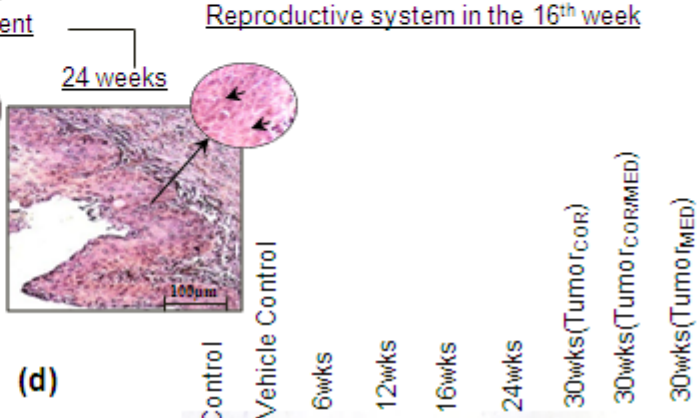

\section{Figure 5}

Assessing cervical inflammation profile concerning COX2 (a) Visual representation of mouse splenic anatomy along with their corresponding micrographic histology images in the 16th week of treatment. Images of histological sections ( $5 \mu \mathrm{m}$ thick) are magnified to 200x (original magnifications x 10; scale bar: $200 \mu \mathrm{m}$ ). (b) Reproductive system of 3MC-treated mice (16th week) displaying vasculature growth (arrow indicated). (c) Representative IHC micrographs exhibiting spatial distribution of COX2 within the nucleus and cytoplasm of the $3 \mathrm{MC}$-treated mouse cervix tissues in the 16th and 24th weeks. Control and vehicle control images are magnified up to 400X with scale bar of 50 $\mathrm{mm}$; whereas magnification of treatment images are-Main image: 200X; Insets: 400x; upper panel with scale bar: $100 \mu \mathrm{m}$. Graphical portrayal (lower panel) of corresponding intensity (high/low) trends for COX2-specific positive staining in these 3MC-treated (16 and 24 weeks) cervical tissues. (d) Western blot results depicting COX2 expression in the total tissue lysates of Group III mouse cervix. (e) Concomitant COX2 kinetics (U/mg of protein) in the cervical tissue lysates of the corresponding mouse groups. Numerical data were represented as Mean \pm S. D of three independent experiments ( ${ }^{*} p<0.005$ vs Control; $\left.N=10\right)$ 


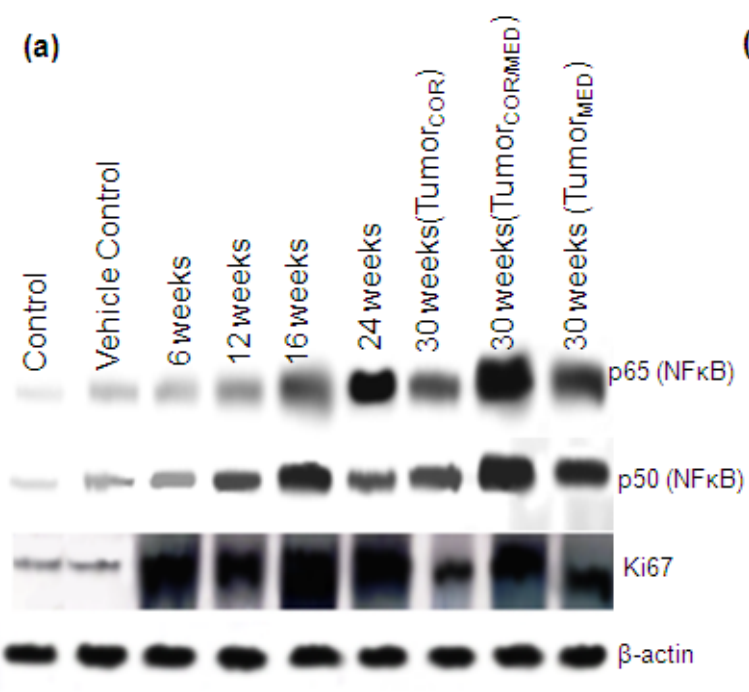

(b)
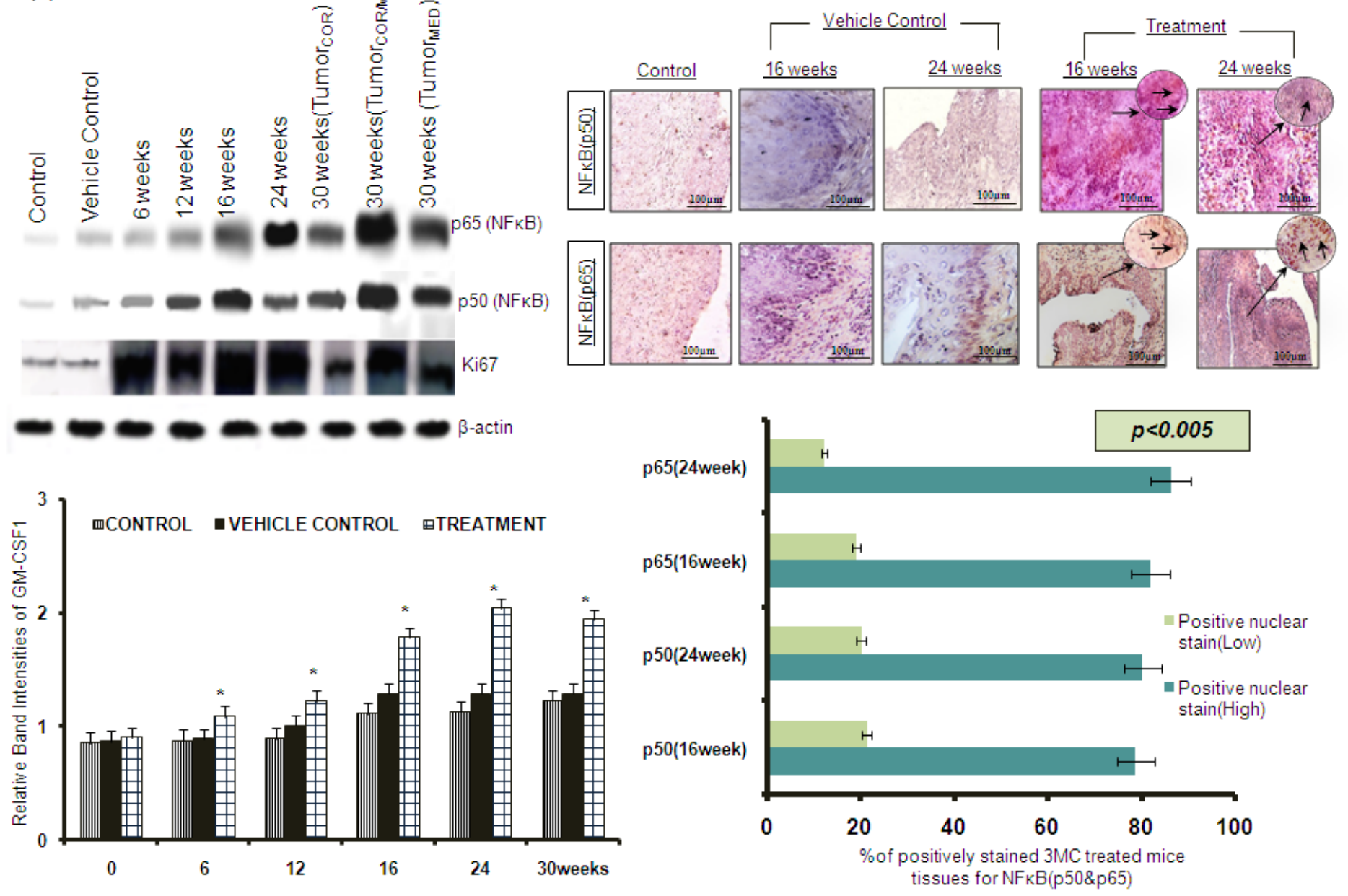

Fig. 6.

\section{Figure 6}

Protein expression of COX2 effector molecules with prosurvival significance (a) Western blot results delineating comparative profiles of NFKB (p65), NFkB (p50), GM-CSF1 and Ki67 protein expression. (b) Microscopic overview of tissue-specific localization of NFKB (p65/p50) in mouse cervical tissues as studied by IHC analysis. Corresponding graphical overview (lower panel) of the cervical protein expression dynamics as represented in terms of positive staining intensity (high/low) scores. Magnifications of main images are 200X (original magnifications $\times 10$; scale bar: $100 \mu \mathrm{m}$ ) and that of the respective highlighted insets are magnified to 400X. Numerical data represented as Mean \pm S. D of three independent experimental replicates, where *p<0.005 vs Control is considered statistically significant 


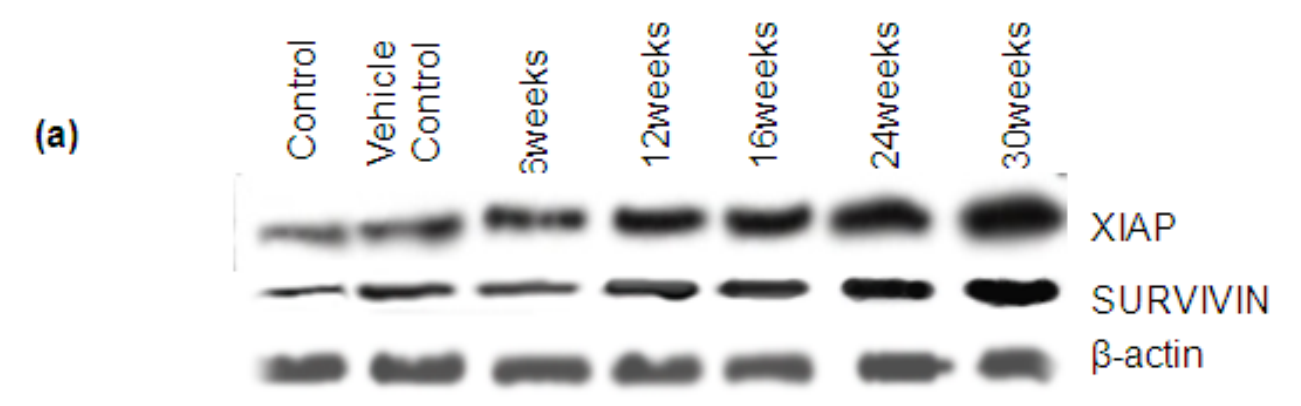

(b)

Fig. 7.
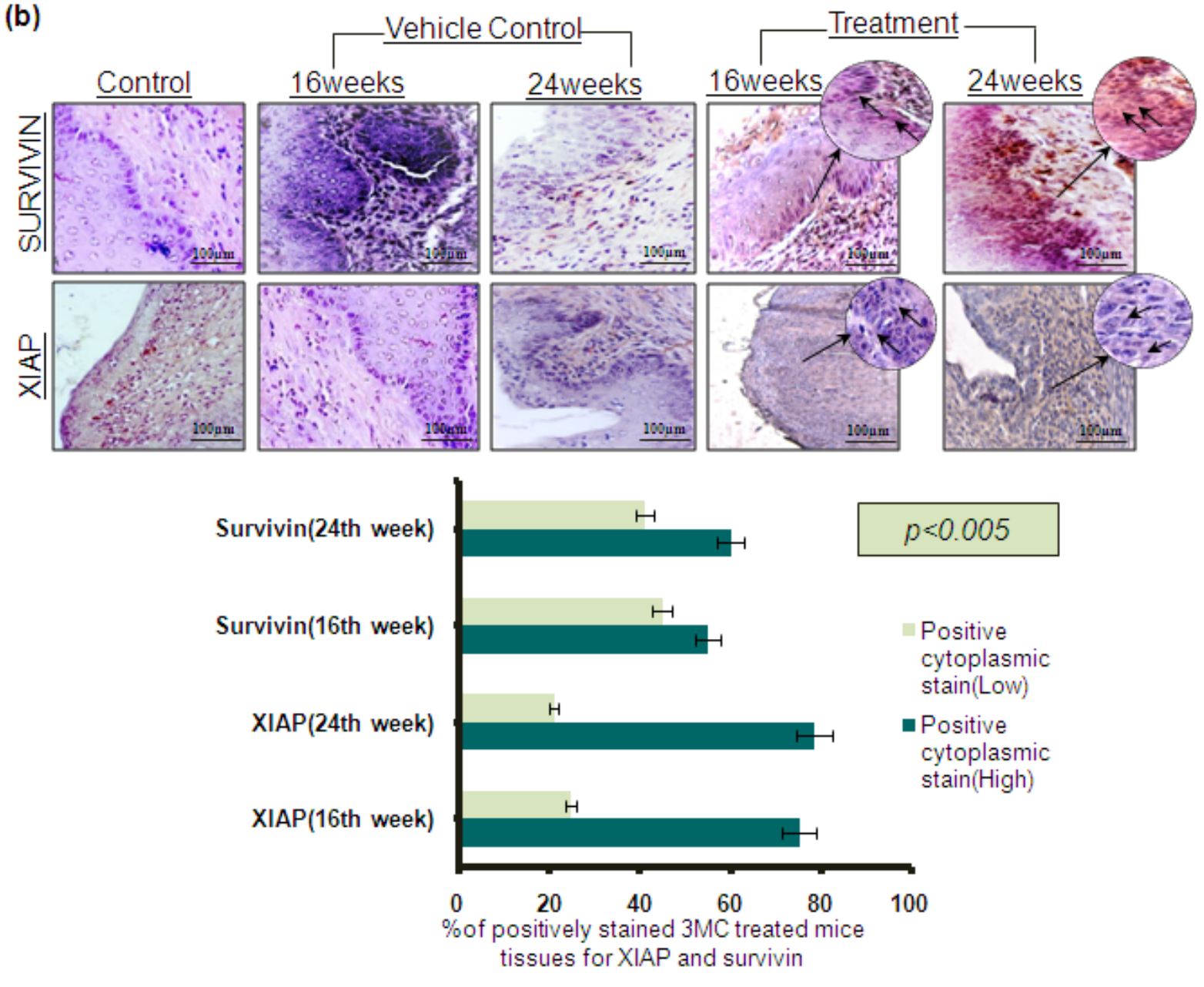

Figure 7

COX2-driven expression of IAPs during cervical cancer progression in mice (a) Comparative shifts and drifts in the protein expression profiles of XIAP and survivin in mouse cervical tissue lysates obtained from different $3 \mathrm{MC}$ treatment groups. (b) IHC micrographs (Main image: 200X; Insets: 400X; scale bar: $100 \mu \mathrm{m}$ upper panel) indicating tissue-specific XIAP and survivin expression in the mouse cervix of Group III vs. Group II and I. Along with its positive staining intensities (high/low) being expressed in a graphical anecdote. Data (Mean \pm S. D) are documented from three independent experimental replicates; ${ }^{*} p<0.005$ vs Control 
(a)
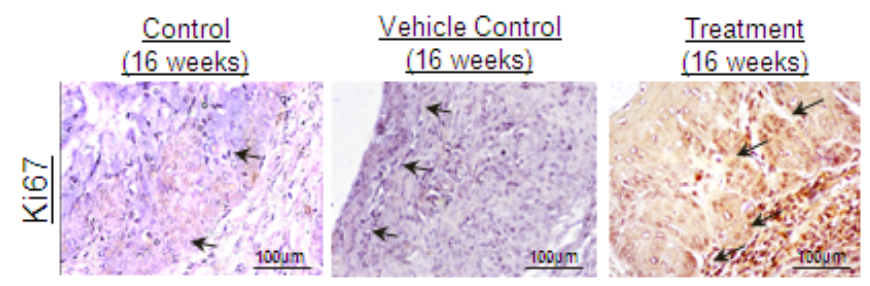

Treatment (After 24 weeks)
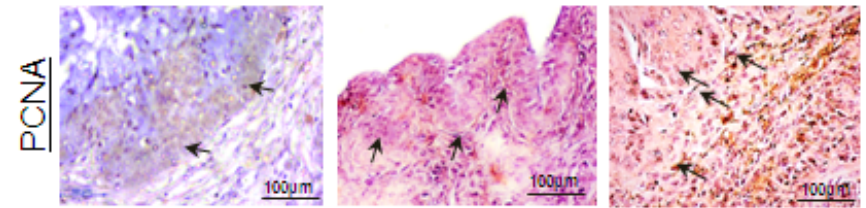

(b)

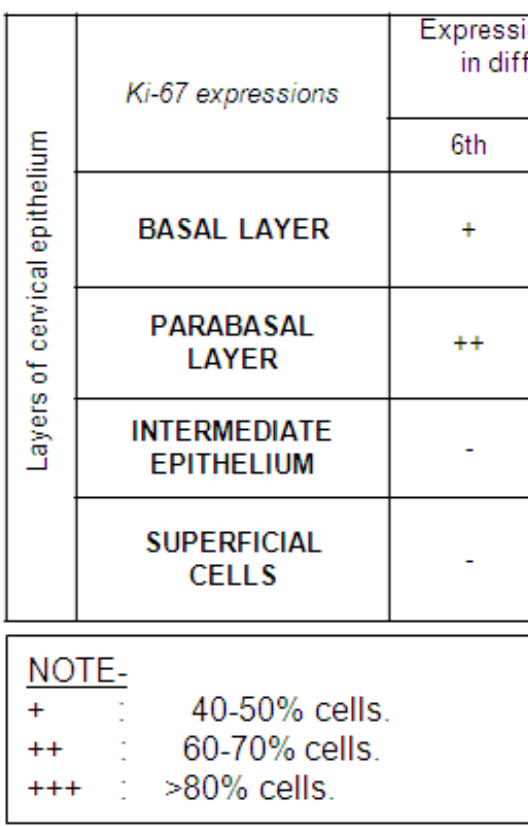

\begin{tabular}{|c|c|c|c|c|}
\hline \multirow{6}{*}{ 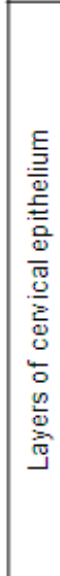 } & \multirow[t]{2}{*}{ PCNA expressions } & \multicolumn{3}{|c|}{$\begin{array}{l}\text { Expression patterns PCNA in } \\
\text { differential weeks of } \\
\text { treatment }\end{array}$} \\
\hline & & 6th & $16 \mathrm{th}$ & 30th \\
\hline & BASAL LAYER & + & ++ & ++ \\
\hline & $\begin{array}{l}\text { PARABASAL } \\
\text { LAYER }\end{array}$ & ++ & ++ & ++ \\
\hline & $\begin{array}{l}\text { INTERMEDIATE } \\
\text { EPITHELIUM }\end{array}$ & - & ++ & ++ \\
\hline & $\begin{array}{l}\text { SUPERFICIAL } \\
\text { CELLS }\end{array}$ & - & + & + \\
\hline
\end{tabular}

Fig. 8.

\section{Figure 8}

Elevated COX2 accelerated the tissue proliferative potential of the mouse cervix (a) IHC exhibits the status of proliferative antigens Ki67 and PCNA in the mouse cervical tissues (Groups I, II and III). Respective image magnifications are 200X (original magnifications). Area of interest is $100 \mu \mathrm{m}$ as per scale bar indications. (b) Cellular immunostaining intensities (lower panel) in the basal, parabasal, intermediate and superficial layers of the cervical stratified epithelium are semiquantitatively represented in terms of the frequency of microscopically recorded positively stained cells. 
(a)
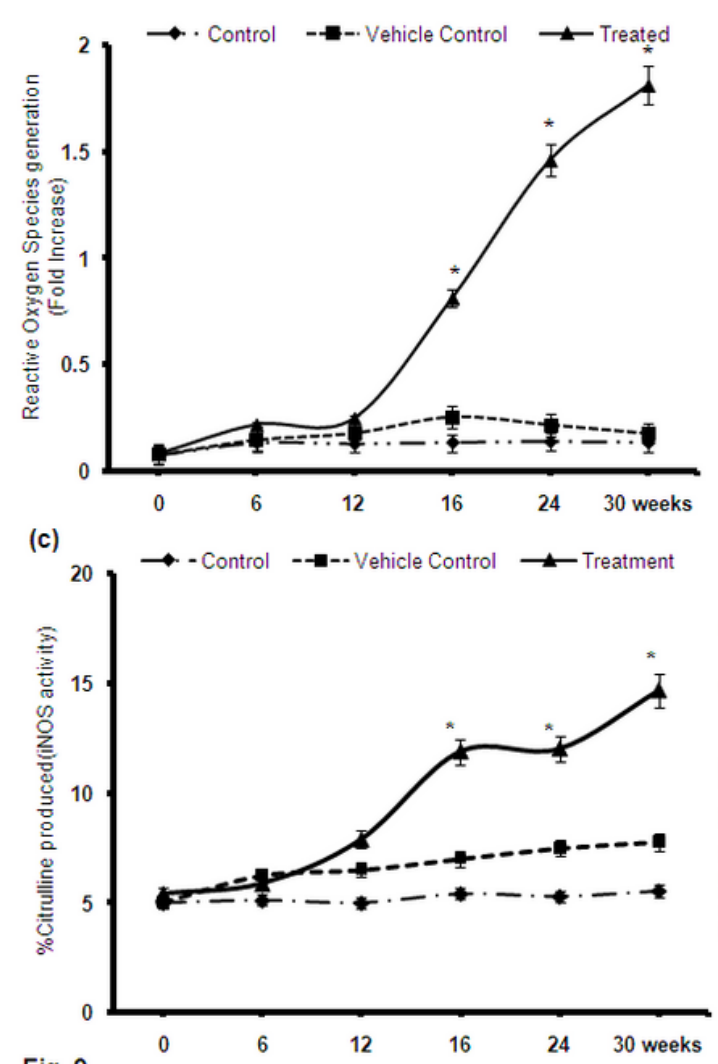

Fig. 9. (b)
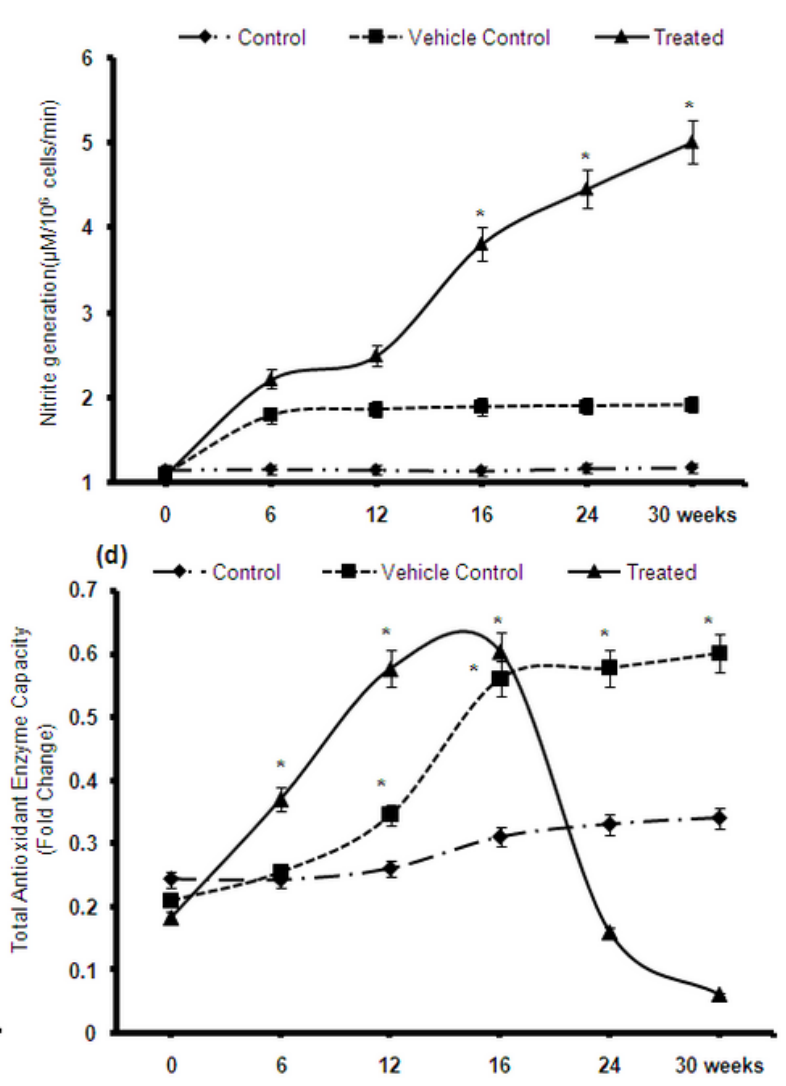

\section{Figure 9}

Activated COX2 accounted for persistent/restraint systemic stress in mice (a-c) Dynamics of 3MC-induced systemic stress are expressed in terms of free radical (ROS and RNS) generation along with quantitative estimation of iNOS activity in isolated blood leukocytes and peritoneal macrophages of mice ( $n=10$; Groups I, II and III). (d) Relative total antioxidant capacities of the corresponding mouse groups differentially treated with $3 M C$ PET. Numerical values are represented as Mean \pm S.D. The results were significant at ${ }^{*} p<0.005$ vs Control. Experiments were done in triplicates 
(a)
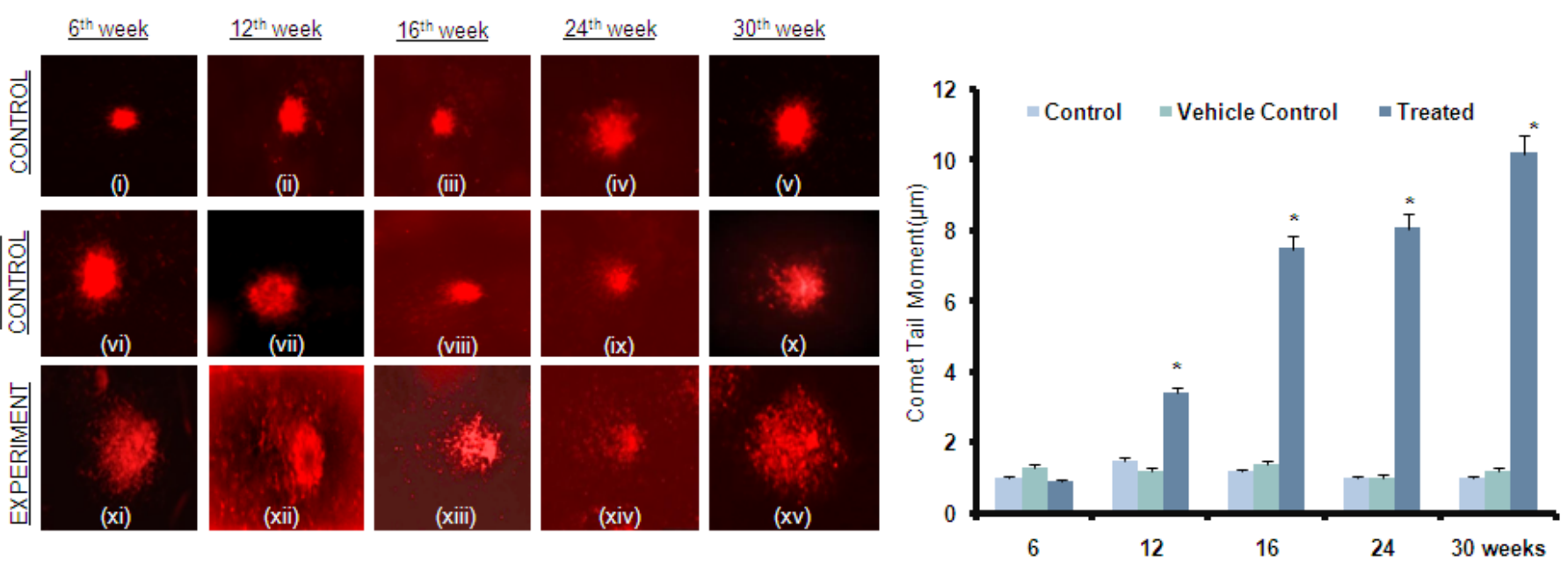

(b)

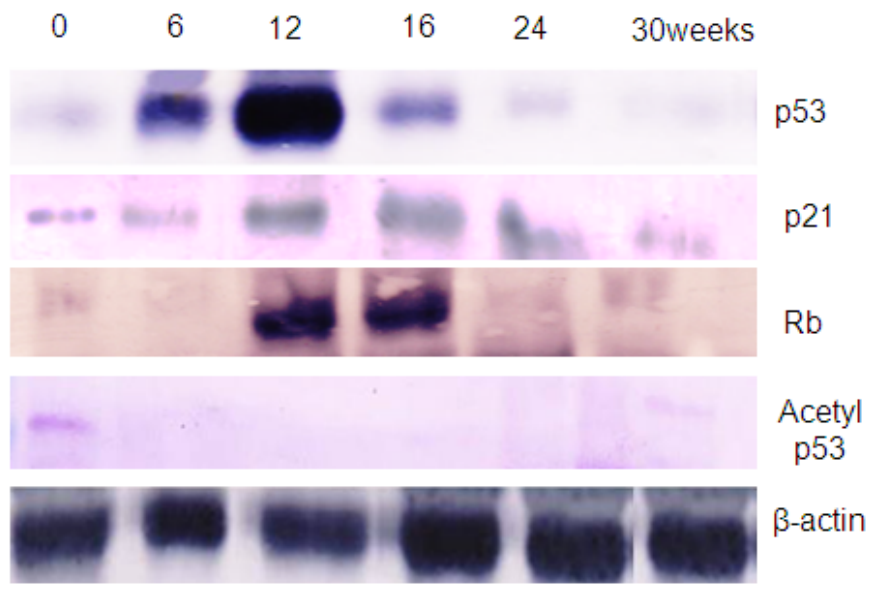

Fig. 10.

\section{Figure 10}

Possible involvement of COX2-mediated systemic stress in inducing DNA damage by hampering tumor suppressor protein function in mice a) Comet assay images (upper left panel) depicting DNA damage incurred by systemic stress induced by the generated free radicals in Group I, II and III mice followed by a graphical overview (upper right panel) of the relative DNA damage intensities (Mean $\pm S$. $D, n=10,{ }^{*}<0.005$ ) (b) Expression patterns (lower panel) of tumor suppressor proteins (p53, p21, Rb and acetylated p53) as studied by western blot analysis specifically in the cervix tissue lysates of Group III mice. Experiments are repeated twice 


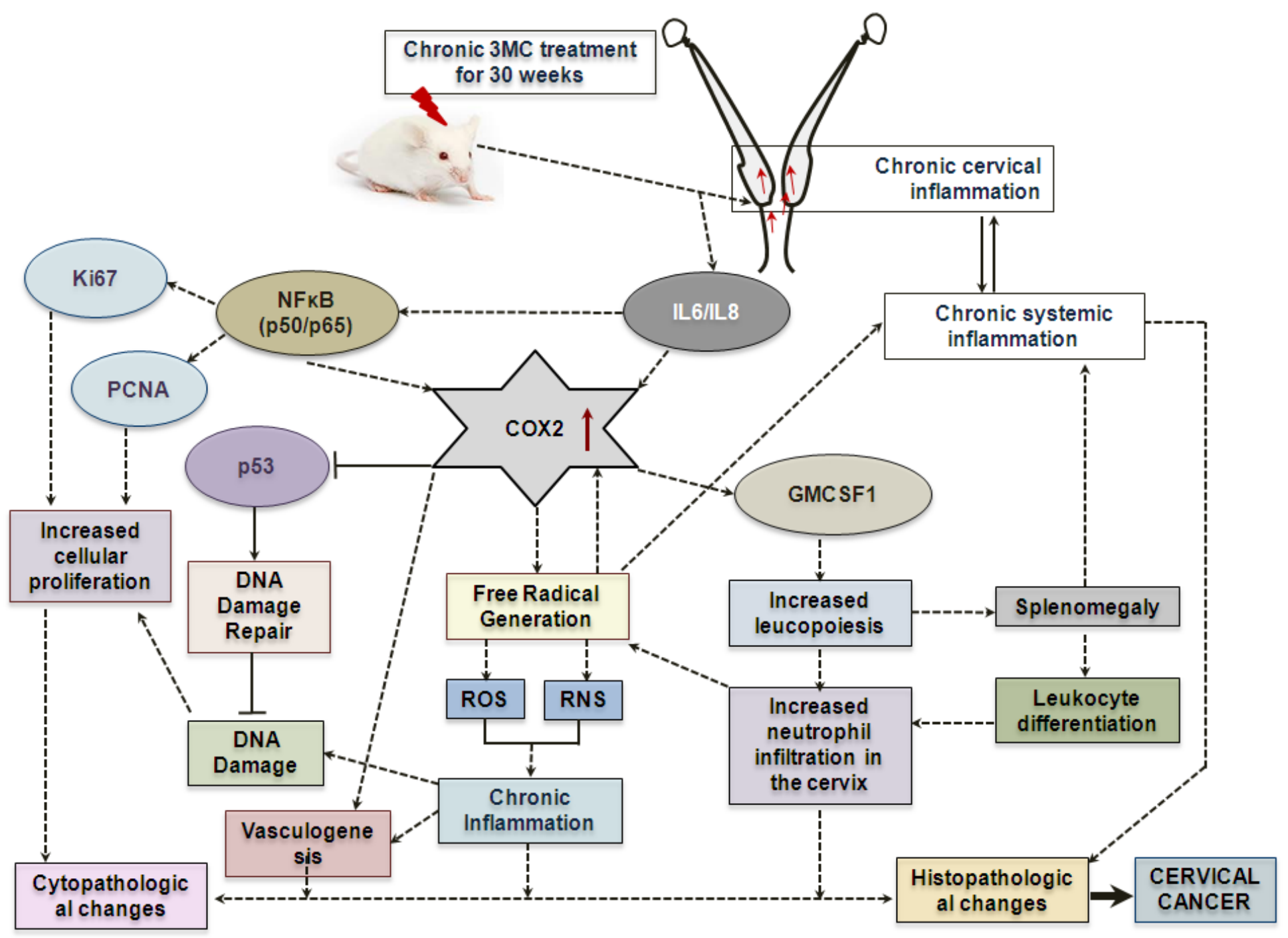

Fig. 11.

\section{Figure 11}

Conclusive overview of the study Schematic representations of the COX2-associated probable factors fueling neoplastic progression. This inflammation-mediated prosurvival factor favoured the formation of a signalling nexus that prospered in the $3 \mathrm{MC}$-treated mouse cervix owing to ceaseless COX2 activity 